$1-14-2021$

\title{
Error of Law: An Exception to the Discoverability Principle?
}

Samuel Beswick

Peter A Allard School of Law, University of British Columbia

Follow this and additional works at: https://digitalcommons.osgoode.yorku.ca/ohlj

Part of the Law Commons

Article

\section{(c) (1) (9)}

This work is licensed under a Creative Commons Attribution-Noncommercial-No Derivative Works 4.0 License.

\section{Citation Information}

Beswick, Samuel. "Error of Law: An Exception to the Discoverability Principle?." Osgoode Hall Law Journal $57.2(2021)$ : 295-341.

https://digitalcommons.osgoode.yorku.ca/ohlj/vol57/iss2/1

This Article is brought to you for free and open access by the Journals at Osgoode Digital Commons. It has been accepted for inclusion in Osgoode Hall Law Journal by an authorized editor of Osgoode Digital Commons. 


\title{
Error of Law: An Exception to the Discoverability Principle?
}

\begin{abstract}
Under Canadian common law, the limitation principle of discoverability applies to errors of fact, but not to errors of law. This error-of-law exception is a problematic doctrine. It appears to resurrect the ostensibly defunct fact/law distinction in civil claims. It stands in contrast to contemporary English precedent on the discoverability of mistakes of law. It controverts the Supreme Court of Canada's claim that discoverability is a "general rule" for the interpretation of limitation periods on causes of action. And it considerably curtails the reach of the discoverability principle and the potential for plaintiffs labouring under an error of law to benefit from an extended limitation period. In practice, the error-of-law exception may overly curtail rights by protecting those who make legal rules while impeding those who have been harmed by unjust laws. This article develops a revised understanding of the error-of-law rule that strikes a better balance between protecting past reliance interests and vindicating plaintiffs' rightful positions.
\end{abstract}

\section{Creative Commons License}

\section{(c) (i) (8)}

This work is licensed under a Creative Commons Attribution-Noncommercial-No Derivative Works 4.0 License. 


\section{Error of Law: An Exception to the Discoverability Principle?}

\section{SAMUEL BESWICK*}

Under Canadian common law, the limitation principle of discoverability applies to errors of fact, but not to errors of law. This error-of-law exception is a problematic doctrine. It appears to resurrect the ostensibly defunct fact/law distinction in civil claims. It stands in contrast to contemporary English precedent on the discoverability of mistakes of law. It controverts the Supreme Court of Canada's claim that discoverability is a "general rule" for the interpretation of limitation periods on causes of action. And it considerably curtails the reach of the discoverability principle and the potential for plaintiffs labouring under an error of law to benefit from an extended limitation period. In practice, the error-of-law exception may overly curtail rights by protecting those who make legal rules while impeding those who have been harmed by unjust laws. This article develops a revised understanding of the error-of-law rule that strikes a better balance between protecting past reliance interests and vindicating plaintiffs' rightful positions.

\footnotetext{
Assistant Professor, Peter A Allard School of Law, The University of British Columbia. Thank you to John Goldberg, Rebecca Williams, Vicki Jackson, John Kleefeld, Barbara Billingsley, Daniel Zacks, Frederick Wilmot-Smith, Sunny Mathew, Annie Sunny, participants of the Canadian Law of Obligations Conference in May 2019, participants of a Global Seminar on Private Law Theory hosted via Zoom.us in April 2020 by McGill University Faculty of Law's Paul-André Crépeau Centre of Private and Comparative Law, the anonymous reviewers, and the Journal's editors, and, for their generous research grant, the Harvard Weatherhead Center Canada Program.
} 


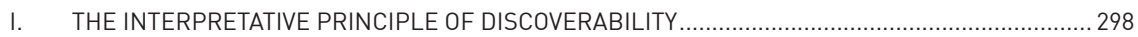

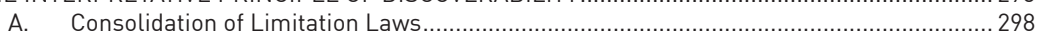

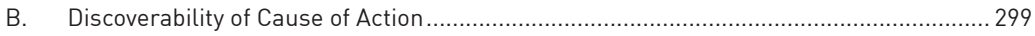

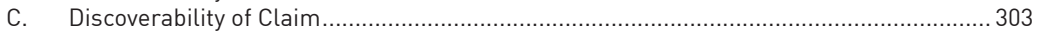

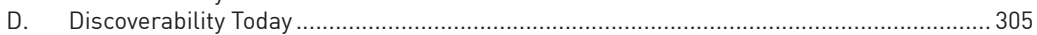

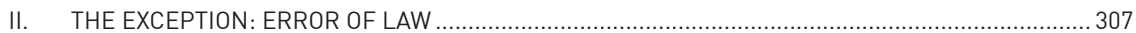

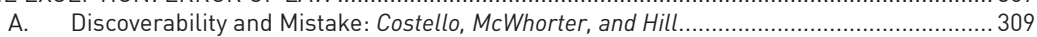

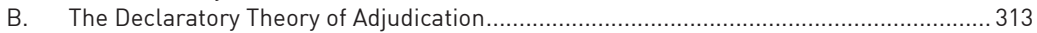

C. Mistaken Understanding of the Law ...................................................................... 314

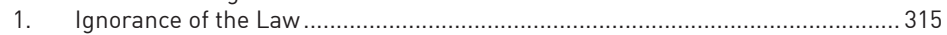

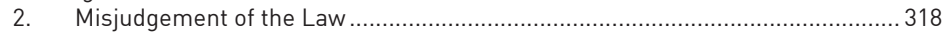

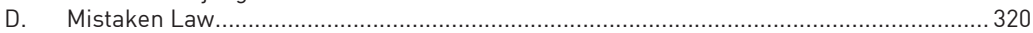

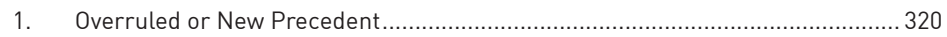

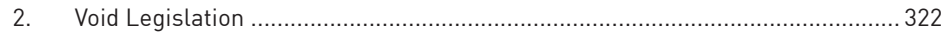

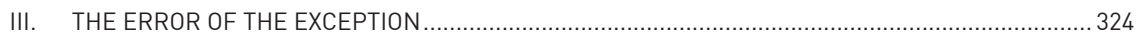

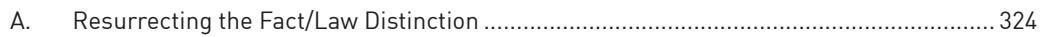

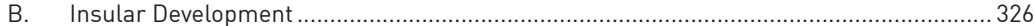

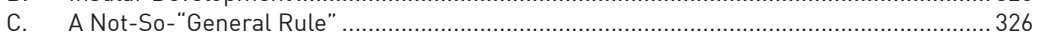

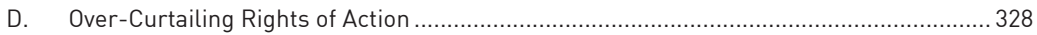

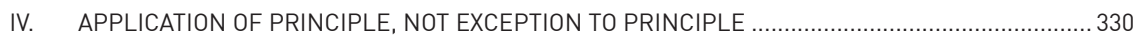

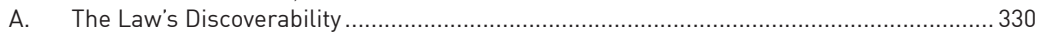

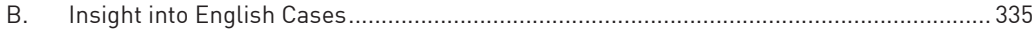

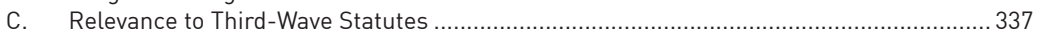

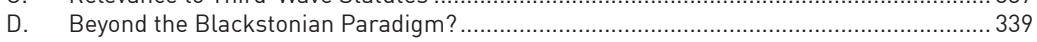

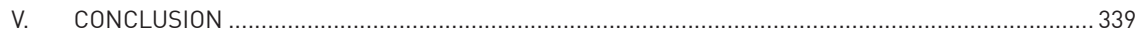

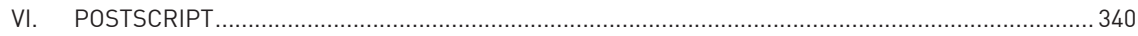

DISCOVERABILITY IS A FAMILIAR PRINCIPLE in the interpretation of limitation provisions in Canada. Rather than construing time to run from the date at which damage or loss occurs, limitation usually runs from when a plaintiff discovered, or could with reasonable diligence have discovered, their right of action. This interpretive presumption was cemented into Canadian common law by two decisions of the Supreme Court of Canada (SCC) in the 1980s. ${ }^{1}$ It has since been assimilated into the drafting of many limitation statutes at the provincial and federal level.

While the discoverability principle is well-known, Canadian common law also recognizes a less familiar exception to the principle in respect of errors of law. It is encapsulated by a sentence in Graeme Mew's treatise, which advises that "[e]rror, ignorance or uncertainty of the law, which may require a potential claimant to diligently obtain legal or other expertise to interpret the facts,

1. Kamloops v Nielsen, [1984] 2 SCR 2 at 40-42 [Nielsen]; Central Trust Co v Rafuse, [1986] 2 SCR 147 at 224 [Rafuse]. 
does not postpone any limitation period." ${ }^{2}$ The effect of this exception is that limitation periods in Canada are generally not deferred on account of mistake of law, including misjudgements of legal rights or practice, the overruling of precedent, and judicial declarations of void or unconstitutional legislation. A plaintiff's cause of action in such cases typically arises when they suffer a loss or damage, not when they discover their error of law.

The error-of-law exception to discoverability is significant. It appears to resurrect the ostensibly defunct fact/law distinction in civil claims. ${ }^{3}$ It stands in contrast to contemporary English precedent on the discoverability of mistakes of law. ${ }^{4}$ It controverts the SCC's claim that discoverability is a "general rule" for interpreting how limitation runs against causes of action. ${ }^{5}$ And it considerably curtails the reach of the discoverability principle and the potential for plaintiffs labouring under an error of law to benefit from an extended limitation period.

This article seeks to shine a light on this distinct rule of law. It has three objectives. The first is descriptive. Parts I and II address Canada's common law discoverability principle and demonstrate the existence and breadth of the error-of-law exception in the doctrine. Though the rule has significant import, it has received only fleeting attention in scholarship to date.

Part III is critical. It contends that, despite its prevalence in case law, Canada's exception to the discoverability principle is jurisprudentially shallow. Courts have often applied it with only brief reasoning, without explaining how the rule fits Canada's common law jurisprudence, and without acknowledging the clear conflict with English precedent.

Part IV is constructive. It sets out a revised understanding of error of law vis-à-vis the interpretation of limitation provisions. On each side of the Atlantic, the courts have adopted their own firm rules: In Canada, errors of law are considered never to defer the running of limitation, whereas in England, they have been presumed always to postpone the limitation clock. Part IV proposes a middle path between these two polar positions by reconstructing the Canadian rule not as an exception to discoverability, but as the presumptive application of the principle of discoverability. It is for plaintiffs to rebut the presumption that

2. The Law of Limitations, 3rd ed (LexisNexis, 2016) at para 3.52 [Mew, Limitations].

3. CfAir Canada v British Columbia, [1989] 1 SCR 1161 at 1201, La Forest J [Air Canada]; Canadian Pacific Air Lines Ltd v British Columbia, [1989] 1 SCR 1133 at 1156-57, La Forest J [Canadian Pacific Air Lines].

4. See Samuel Beswick, "The Discoverability of Mistakes of Law" [2019] LMCLQ 112 [Beswick, "Discoverability of Mistakes of Law"].

5. Rafuse, supra note 1 at 224. See Pioneer Corp v Godfrey, 2019 SCC 42 at paras 34-38 [Pioneer Corp]. Cf Pioneer Corp, ibid at paras 140-50, Côté J, dissenting. 
errors of law are discoverable when they are made. Properly understood, the Canadian inclination against tethering limitation to the date of some significant juridical event is sound. This article's approach to discoverability as it relates to errors of law rationalizes the Canadian understanding and shows how it might also guide a re-evaluation of English jurisprudence in this area. It improves the balance between private interests in vindicating timely legal claims and the public policies that underlie statutes of limitation, which protect individuals and government alike.

\section{THE INTERPRETATIVE PRINCIPLE OF DISCOVERABILITY}

In broad terms, Canada's provinces have experienced three waves of statutory limitation reform. ${ }^{6}$

\section{A. CONSOLIDATION OF LIMITATION LAWS}

Consolidation was the focus of the first wave of reform. In the 1930s, provinces undertook to amalgamate their diffused limitation provisions into single limitation statutes. ${ }^{7}$ This first wave of provincial limitation legislation largely inherited its drafting language and principles from England. ${ }^{8}$ The ordinary limitation period was six years. ${ }^{9}$ It commenced from when "the cause of action

6. See Mew, Limitations, supra note 2 at paras 1.12-1.47.

7. See John D Falconbridge, "The Disorder of the Statutes of Limitation" (1943) 21 Can Bar Rev 669 at 670.

8. Everett Lane Weaver, Limitations: Being a Treatise on the Time Limit on Actions in Canada, ed by AE Laverty (Canadian Law List, 1939) at 1; Jeremy S Williams, Limitation of Actions in Canada, 2nd ed (Butterworth \& Co, 1980) at 26; Alberta, Institute of Law Research and Reform, Limitations, Report for Discussion No 4 (1986) at 12.

9. See e.g. The Limitations of Actions Act, ULCC 1931, cl 3(1)(j) [Uniform Limitations Act 1931] in Ontario Law Reform Commission, Report on Limitation of Actions (1969), Appendix C. The Uniform Limitations Act 1931 provided a two-year limit for personal injury, defamation, and certain other actions. See also Weaver, supra note 8, citing Limitations Act, RSO 1937, c 118 [Ontario, Limitations Act 1937]. The Ontario, Limitations Act 1937 prescribed several different limitation periods depending on the cause of action. 
arose." ${ }^{10}$ The Uniform Limitations Act 1931, which precipitated these reforms, ${ }^{11}$ provided exceptions in cases of fraudulent misrepresentation, ${ }^{12}$ concealed fraud,,${ }^{13}$ and for "actions grounded on accident, mistake or other equitable ground of relief." 14 In such cases, the ordinary period of limitation ran not from when the cause of action occurred, but from "discovery" of the action. Ontario ${ }^{15}$ and British Columbia ${ }^{16}$ did not adopt the Uniform Act. Although both provinces recognized equitable rules that postponed the running of time in some circumstances of "mistake," their scope and application came to be considered as "neither clear nor sufficient." 17

\section{B. DISCOVERABILITY OF CAUSE OF ACTION}

The problem of latent or concealed causes of action becoming statute-barred before a plaintiff could reasonably discover them spurred a second wave of

10. Uniform Limitations Act 1931, supra note 9 at $\mathrm{cl} 3$ (defining an "action" as "any civil proceeding" at cl 2(a)); Limitations Act, RSO 1960, c 214, s 45; Limitation Act 1939 (E\&W), 2 \& 3 Geo 6, c 21 (defining an "action" as "any proceeding in a court of law" at s 31(1)) [Limitation Act $1939 \mathrm{E} \& \mathrm{~W}$ ]. See Daniel Zacks, "Claims, Not Causes of Action: The Misapprehension of Basic Limitations Principles" (2018) 48 Adv Q 165 at 171-72 ("[d]epending on one's preference, a cause of action completes, accrues, arises, or ripens. This language all means the same thing: the date on which the cause of action first becomes viable" at 169, n 12); Nykredit Mortgage Bank Plc v Edward Erdman Group Ltd (No 2), [1997] 1 WLR 1627 at 1638 (HL Eng), Lord Hoffmann [Nykredit Mortgage Bank Plc]; Costello v Calgary (City) (1989), 60 DLR (4th) 732 at 741 (Alta CA) [Costello 1989 Alta CA].

11. Mew, Limitations, supra note 2 at para 1.11. The Uniform Limitations Act 1931 was the basis for the limitation statutes acts enacted in Manitoba (1931), Saskatchewan (1932), Alberta (1935), Prince Edward Island (1939), the Northwest Territories (1948), New Brunswick (1952), and Yukon (1954) (ibid).

12. Uniform Limitations Act 1931, supra note 9 at $\mathrm{cl} 3(1)(\mathrm{g})$.

13. Ibid, $\mathrm{cl} 4$.

14. Ibid, $\mathrm{cl} 3(1)(\mathrm{h})$.

15. Ontario, Limitations Act 1937, supra note 9; Limitations Act, SO 1966, с 214.

16. Statute of Limitations, RSBC 1897, c 123; Statute of Limitations, RSBC 1960, c 370.

17. Ontario Law Reform Commission, Report on Limitation of Action (1969) at 109; Law Reform Commission of British Columbia, Report on Limitations: Project No 6, Report 15 (1974) at 95, citing Law Revision Committee of England and Wales, Fifth Interim Report: Statutes of Limitation (1936) at 29-32. 
limitation reform in the latter half of the last century. ${ }^{18}$ As in England, ${ }^{19}$ provincial legislatures enacted more expansive discoverability provisions. ${ }^{20}$ These reforms largely maintained the principal drafting technique of tethering the running of the limitation period to the cause of action, but redefined the point at which the affected action "arises." For example, Manitoba introduced a discoverability standard for personal injury claims into its limitation statute in $1967,{ }^{21}$ modelled after the 1963 English legislation, ${ }^{22}$ and expanded the statutory principle in $1980^{23}$ following the English Court of Appeal's watershed judgment five years earlier in Sparham-Souter $v$ Town \& Country (Essex) Ltd. ${ }^{4}$ Judges, too, came to reconsider their understanding of limitation provisions. In Sparham-Souter, a decision concerning latent building defects, the Court of Appeal of England and Wales set new precedent in holding that a negligence action "does not accrue,

18. Mew, Limitations, supra note 2 at paras 1.12-1.50; New Brunswick, Office of the Attorney General Law Reform Branch, Limitations Act, Discussion Paper (1988) at 4. For a list of modern English reform reports on limitation, see NH Andrews, "Reform of Limitation of Actions: The Quest for Sound Policy" (1998) 57 CLJ 589 at 589, n 1. For the position in the United States, see Calvin W Corman, Limitation of Actions, vol 2 (Little, Brown \& Co, 1991) at para 11.2; Ehud Guttel \& Michael T Novick, "A New Approach to Old Cases: Reconsidering Statutes of Limitation" (2004) 54 UTLJ 129 at 136, n 9.

19. See Limitation Act 1963 (E\&W), c 47 [Limitations Act $1963 \mathrm{E} \& W$ ] (replaced by Limitation Act 1980, c 58, ss 11, 14); UK, Edmund Davies Committee, Limitation of Actions in Cases of Personal Injury (Cmnd 1829, 1962) (recommending the enactment of the Limitations Act 1963). See also Latent Damage Act 1986 (E\&W), c 37 [Latent Damage Act 1986]; UK, Law Reform Committee, 24th Report on Latent Damage (Cmnd 9390, 1984) at para 4.4 (recommending the enactment of the Latent Damage Act 1986 and inserting Limitation Act 1980, ss 14A, 14B); Limitation Act 1980 (E\&W), c 58, ss 14A-14B.

20. For the most comprehensive early reform, see Limitation Act, SBC 1975, c 37 [Limitation Act 1975 BC]. The Limitation Act 1975 BC was the first Canadian statute to codify a general principle of discoverability. Actions governed by these provisions tended also to be accompanied by shorter headline limitation periods. See Novak v Bond, [1999] 1 SCR 808 at paras 34, 72, McLachlin J [Novak]; Kent Roach, "Reforming Statutes of Limitations" (2001) 50 UNBLJ 25 at 32 (discussing Novak and considering the "obscure" and "troublesome" drafting of British Columbia’s discoverability provision).

21. An Act to Amend the Limitation of Actions Act and to amend Certain Provisions of other Acts relating to Limitations of Actions, SM 1966-67, c 32.

22. Limitation Act $1963 \mathrm{E} \& \mathrm{~W}$, supra note 19. See ABv Ministry of Defence, [2012] UKSC 9 at para 165, Lady Hale SCJ.

23. An Act to Amend the Limitation of Actions Act, SM 1980, c 28.

24. [1976] QB 858 (CA) [Sparham-Souter]. See Manitoba Law Reform Commission, Limitations, (Cameron Harvey, QC) Report 123 (2010) at 15, citing Sparham-Souter [Manitoba Law Reform, Limitations]. See Harris Wineberg, "British Columbia's Statutory Discoverability Rule" (1994) 16 Adv Q 490 at 504-505 (expressing preference for the common law formulation over British Columbia's codification). 
and time does not begin to run, until such time as the plaintiff discovers" that it has suffered "damage, or ought, with reasonable diligence, to have discovered it." ${ }^{25}$ Courts across the Commonwealth took up then-Master of the Rolls Lord Denning's novel interpretation of the accrual of negligence actions ${ }^{26}$ even after the House of Lords repudiated it less than seven years later. ${ }^{27}$

Sparham-Souter was assumed to be good law in Canada when the Court of Appeal for British Columbia ruled in Kamloops $v$ Nielsen that defective building owners were not time-barred from bringing negligence claims for latent damage against the City outside of the ordinary limitation period. ${ }^{28}$ Before a decision on appeal was rendered, ${ }^{29}$ Sparham-Souter was overruled in England, and the SCC was (in the majority's view) called to resolve an interpretative choice in Nielsen: ${ }^{30}$ Did the plaintiffs' cause of action "arise"31 when their building was damaged (in which case their action would be time-barred) or when the plaintiffs were able to discover the defects (in which case their action would be timely)? Justice Wilson, writing for the majority of the Court, endorsed Sparham-Souter: The plaintiffs' cause of action did not arise, and the limitation period did not commence, until the defects became reasonably discoverable. ${ }^{32}$ Whereas the House of Lords in Pirelli General Cable Works Ltd v Oscar Faber \& Partners had found that "the necessary implication" from the express inclusion of a discoverability standard in section 26 of the Limitation Act 1939 was that discoverability was

25. Sparham-Souter, supra note 24 at 868. See Andrew McGee \& Gary Scanlan, "Imputation of Facts-Aspects of s 32(1)(b) of the Limitation Act 1980" (2001) 20 CJQ 17 at 25; James C Morton, Limitation of Civil Actions (Carswell, 1988) at 17-18; Janet O'Sullivan, "Limitation, Latent Damage and Solicitors' Negligence" (2004) 20 Professional Negligence 218 at 229; Zacks, supra note 10 at 171-72. See also Forster v Outred \& Co (1981), [1982] 1 WLR 86 (CA).

26. See e.g. Invercargill City Council v Hamlin, [1994] 3 NZLR 513 (NZCA), affd [1996] 1 NZLR 513 (PC).

27. The House of Lords held that a principle of reasonable discoverability was not to be inferred into the interpretation of English limitation provisions that did not explicitly incorporate it. Pirelli General Cable Works Ltd v Oscar Faber \& Partners, [1983] 2 AC 1 (HL Eng) [Pirelli]. Parliament responded by enacting the Latent Damage Act 1986, supra note 19. See also Anns $v$ Merton London Borough Council, [1978] AC 728, Lord Salmon (expressing the view that the cause of action arose "when the building began to sink and the cracks appeared" at 770).

28. (1981), 129 DLR (3d) 111 at 122-23 (BCCA).

29. Rafuse, supra note 1 at 221; Pirelli, supra note 27. Pirelli was decided after oral submission in Nielsen, so the SCC called for written submissions on the question. See Nielsen, supra note 1.

30. Nielsen, supra note 1 at 40.

31. Municipal Act, RSBC 1960, c 255, s 738 [Municipal Act 1960 BC]. The one-year limitation provision in issue was the Municipal Act 1960 BC.

32. Nielsen, supra note 1 at 39-40. 
not to be implied into the statute's other provisions, ${ }^{33}$ Justice Wilson in Nielsen disagreed that the equivalent statutory schemes before her necessarily confined discoverability to cases of fraud, concealment, and mistake. ${ }^{34}$ Discoverability could aid the interpretation of a cause of action's accrual generally. Justice Wilson acknowledged the problem of discoverability potentially extending the time for bringing an action many years after its occurrence. ${ }^{35}$ But weighed against "the injustice of a law which statute-bars a claim before the plaintiff is even aware of its existence," the interpretative discoverability principle was seen "to be much the lesser of two evils." ${ }^{36}$ Two years later, a unanimous SCC in Central Trust Co $v$ Rafuse reaffirmed the judgment of the majority in Nielsen as laying down a "general rule" that "a cause of action arises for purposes of a limitation period when the material facts on which it is based have been discovered or ought to have been discovered by the plaintiff by the exercise of reasonable diligence." ${ }^{37}$

Over the next decade, despite some resistance, ${ }^{38}$ discoverability came to be adopted as a principle of general application to the interpretation of when a cause of action accrues or arises ${ }^{39}$ under Canadian limitation statutes. ${ }^{40}$ The SCC in Peixeiro v Haberman described the principle as "an interpretive tool ... which ought to be considered each time a limitations provision is in issue." ${ }^{.11}$ It has, accordingly, been broadly employed. Discoverability applies where a statute provides that no action shall be brought beyond $\mathrm{X}$ years "after the cause of any

33. Pirelli, supra note 27 at 14-15, citing Cartledge v E Jopling \& Sons Ltd, [1963] AC 758 (HL Eng) [Cartledge]. See also Pirelli, supra note 27, Lord Fraser (noting that after the post-Cartledge statutory amendment, "Parliament deliberately left the law unchanged so far as actions for damages of other sorts was concerned" at 14).

34. Nielsen, supra note 1 at 40.

35. Ibid.

36. Ibid.

37. Rafuse, supra note 1 at 224 [emphasis added]. See Joost Blom, "Concurrent Liability in Tort and Contract-Start of Limitation Period" (1987) 21 UBC L Rev 429; Nicholas J Mullany, "Limitations of Actions: Where Are We Now?" [1993] LMCLQ 34 at 39.

38. See Alberta Law Reform Institute, Limitations, Report 55 (1989) at 26-27 [ALRI Limitations]; Richard W Bauman, "The Discoverability Principle: A Time Bomb in Alberta Limitations Law" (1993) 1 Health LJ 65 at 79.

39. Zacks, supra note 10 at 169. See Nykredit Mortgage Bank Plc, supra note 10 at 1638, Hoffmann LJ; Costello 1989 Alta CA, supra note 10 at 741.

40. See $M(K) v M(H)$, [1992] 3 SCR 6; Canada $(A G) v$ Lameman, 2008 SCC 14 [Lameman]. See also Graeme Mew, "When Does Time Start to Run? When Does Time Run Out? When Does the Clock Stop Running?” (2004) 28 Adv Q 448 at 452-53 [Mew, "When Does Time Start to Run"].

41. [1997] 3 SCR 549 at para 37 [Peixeiro]. For the Supreme Court's most recent review of the principle, see Pioneer Corp, supra note 5 at paras 31-42. 
such action arose" 42 or "shall have first arisen," ${ }^{43}$ or "from the discovery of the cause of action." ${ }^{44}$ Thus, even statutory language that incorporates a knowledge-based inquiry is construed as complementary with common law discoverability. ${ }^{45}$ Discoverability also applies when limitation is triggered by an element of an underlying cause of action, such as where an action must be brought within $\mathrm{X}$ years from when prohibited "conduct was engaged in," 46 or where an action for the recovery of damages must be brought within X years "from the time when the damages were sustained," ${ }^{47}$ or where an action arising by reason of a deprivation of land must be brought within X years "from the date when the deprivation took place." ${ }^{48}$ In each case, the interpretation converges on the same construction: That time does not begin to run until the date of the plaintiff's discovery or discoverability of their action.

\section{DISCOVERABILITY OF CLAIM}

The interpretive discoverability principle did not settle discontent with Canada's limitation laws. ${ }^{49}$ Three problems persisted. First, discoverability exacerbated inconsistencies in the running of limitation between different causes of action. ${ }^{50}$ Second, it gave rise to the possibility that "undiscovered" actions could potentially be indefinitely postponed until such point as a claimant's cause of action became

42. Rafuse, supra note 1 at 217, citing Statute of Limitations, RSNS 1967, c 168, s 2(1)(e) [Statute of Limitations 1967]; Costello 1989 Alta CA, supra note 10 at 735, citing Limitation of Actions Act, RSA 1980, c L-15, s 51(f) [Limitation of Actions Act 1980].

43. Nielsen, supra note 1 at 40, citing Municipal Act 1960 BC, supra note 31, s 738.

44. Lameman, supra note 40 at para 14, citing Limitation of Actions Act 1980, supra note 41, s 4(1)(e)). See Uniform Limitations Act 1931, cl 3(1)(h).

45. Nielsen, supra note 1 at 42; Novak, supra note 20 at para 10.

46. Pioneer Corp, supra note 5 at paras 43-44, citing Competition Act, RSC 1985, c C-34, s 36(4)(a)(i).

47. Hope $v$ RM of Parkdale \#498, 2013 SKPC 176 at para 59, citing The Municipalities Act, SS 2005, c M36.1, s 344(1)); Peixeiro, supra note 41 at para 11, citing Highway Traffic Act, RSO 1990, c H-8, s 206(1).

48. Hill v South Alberta Land Registration District (1993), 100 DLR (4th) 331 at 337 (Alta CA) [Hillv Alberta Alta CA]; McWhorter v Alberta (North Alberta Land Registration District), [1988] 3 WWR 132 at para 18 (Alta QB) (CanLII) [McWhorter Alta QB], affd on other grounds [1989] 5 WWR 183 (Alta CA) [McWhorter CA]. Both considering s 168(1)(a) of the Land Titles Act 1980. See Land Titles Act, RSA 1980, c L-5, s 168(1)(a). See also Fleming $v$ Hanna, (1994) 124 Nfld \& PEIR 30 (NL SC) (considering The Medical Act, 1974, Stats Nfld No 119, s 25A.A, as amended by 1975, No 13, s 2; Hospitals Act, 1971, SN 1971, No 81, s 37, as amended by 1973, No 118 and 1983, c 49, s 1).

49. Zacks, supra note 10 at 170 ; Roach, supra note 20 at 40 . See Guttel \& Novick, supra note 18 at 179 (providing an economic analysis and critique of contemporary limitation law).

50. See Blom, supra note 37 at 438-439, 443-448; Zacks, supra note 10 at 182. 
reasonably discoverable. ${ }^{51}$ Except where longstop provisions $s^{52}$ or the equitable doctrine of laches applied, ${ }^{53}$ courts would not infer an outer limit on when a claim could be brought. The potential for claims to lie dormant for decades undermined core principles of certainty and finality. ${ }^{54}$ Third, discoverability could also, counterintuitively, lead to actions expiring before a claim could feasibly be brought. It has, for instance, been a "primary stumbling block" to litigating claims concerning historic sexual abuse. ${ }^{55}$

In response, a third wave of limitation reform has spread to supersede the old law. The modern Limitation of Actions Acts abandon the framework of cause-of-action accrual. ${ }^{56}$ In these Acts, it is the "claim," ${ }^{57}$ not the particular "cause of action," that determines the running of limitation. Cause of action and claim are not synonymous. The former is a precondition of the latter, ${ }^{58}$ but one only has a claim once one can plead a right to a remedy. Under the modern drafting, limitation commences once it is discoverable both that a claimant had a claim and that civil proceedings over it were "warrant[ed]" or "appropriate."

51. Bauman, supra note 38 at 79; Mullany, supra note 37 at 48.

52. See Roach, supra note 20 at 26, 42, 44-46.

53. See Bauman, supra note 38 at 80-82; Francis A Anglin, Limitations of Actions Against Trustees (Canada Law Book Company, 1900) at 9-10.

54. See generally Jeremy Waldron, "Superseding Historic Injustice" (1992) 103 Ethics 4; Arthur Ripstein, "The Rule of Law and Time's Arrow" in Lisa M Austin \& Dennis Klimchuk, eds, Private Law and the Rule of Law (Oxford University Press, 2014) 306.

55. Graeme Mew \& Adrian Lomaga, "Abusive Limits: $M(K) v M(H)$ and a Comparison of the Limitation for Sexual Assault” (2009) 35 Adv Q 133 at 134. See Elizabeth Adjin-Tettey \& Freya Kodar, "Improving the Potential of Tort Law for Redressing Historical Abuse Claims: The Need for a Contextualized Approach to the Limitation Defence" (2010) 42 Ottawa L Rev 95 at 117.

56. Such statutes have been enacted in Alberta (1996), Ontario (2002), Saskatchewan (2004), New Brunswick (2009), British Columbia (2012), and Nova Scotia (2014). The Manitoba Law Reform Commission proposed reforms, which have not been enacted. See The Manitoba Law Reform, Limitations, supra note 24; Mew, Limitations, supra note 2 at para 3.66; Pioneer Corp, supra note 5 at para 32.

57. Uniform Law Conference of Canada, Uniform Limitations Act (2005) (establishing that "claim' means a claim to remedy an injury, loss or damage that occurred as a result of an act or omission," cl 1).

58. Zacks, supra note 10 at 182 .

59. See Limitations Act, RSA 2000, c L-12, s 3(1)(a)(iii) [Alberta Limitations Act]; Uniform Limitations Act (2005), s 5(a)(iv); Limitations Act, SO 2002, c 24, s 5(1)(a)(iv). See also Manitoba Law Reform, Limitations, supra note 24 at 21 ("This provision, in its different forms, is intended to recognize that the nature or extent of the injury or damage suffered may not be immediately apparent, and to avoid forcing plaintiffs into litigating unnecessarily over minor damage in order to preserve their rights."). 
sue is further constrained by default ultimate limitation periods that apply across the board, subject to prescribed exceptions and extensions. ${ }^{60}$ For provinces that have modernized their limitation statutes, this third wave of limitation reform marks a break from English limitation law. It also hails a departure from Canada's traditional understanding of the judge-made discoverability principle, ${ }^{61}$ since the statutory discoverability provisions take precedence. Courts nevertheless frequently refer back to the interpretive principle in construing modern limitation statutes. ${ }^{62}$

\section{DISCOVERABILITY TODAY}

Despite the contemporary trend in Canada's provinces toward the statutory "claim"-based framework, common law discoverability remains an important interpretive rule for several reasons. First, the third-wave reforms are best understood as an improvement on, not a clean break with, what came before. Second, not all provinces have abandoned the "cause of action" framework. ${ }^{63}$ Second-wave reform drafting also subsists in key federal limitation statutes, ${ }^{64}$

60. Zacks, supra note 10 at 183-84. See Apotex Inc v Nordion (Canada) Inc, 2019 ONCA 23 at para 86.

61. Zacks, supra note 10 at 165. See Rooplal v Fodor, 2019 ONSC 7211 at para 5 (holding that the discoverability provisions in the Limitations Act, SO 2002, c 24, oust common law discoverability in Ontario).

62. Mew does not draw as sharp a distinction with past limitation regimes as Zacks does. See Mew, Limitations, supra note 2 at paras 3.66, 3.121; Mew, "When Does Time Start to Run," supra note 40. See also HOOPP Realty Inc v Emery Jamieson LLP, 2018 ABQB 276 at paras 174-220 [HOOPP Realty]; Ambrozic v Burcevski, 2006 ABQB 4 at paras 29-32, 59 [Ambrozic]; Waap v Alberta, 2008 ABQB 544 at paras 123-126 [Wapp]; Stewart Estate v TAQA North Ltd, 2013 ABQB 691 at para 197 [Stewart Estate]; Miller v Canada, 2018 FC 599 at paras 91-100 [Miller]; Pecharkky v Pecharsky, 2019 ABQB 219 at paras 90-99 [Pecharsky]; New Brunswickv Thornton, 2020 NBCA 18 at para 92; Equinav Financial Corporation v Roesslein Estate, 2020 SKCA 69 at para 25. For a summary of the legal principles guiding the interpretation of limitation periods, see Condominium Plan No 0625385 v Oxford Grande Ltd, 2017 ABQB 316 at para 20 [Condominium Plan No 0625385]. See also Mew, Limitations, supra note 2 at paras 3.48-3.53.

63. The limitation statutes of Manitoba, Newfoundland and Labrador, Prince Edward Island, Yukon, and the Northwest Territories are still largely influenced by the traditional English drafting and the Uniform Limitations Act 1931.

64. A fallback limitation period that requires proceedings to be brought "within six years after the cause of action arose" is prescribed by two federal acts. See Federal Courts Act, RSC 1985, c F-7, s 39(2); Crown Liability and Proceedings Act, RSC 1985, c C-50, s 32. 
as well as hundreds of particular provincial and federal limitation provisions. ${ }^{65}$ Those statutes remain subject to common law discoverability, as do actions that arose prior to the modern reforms. ${ }^{66}$

Canada's common law understanding of discoverability may also usefully inform the interpretation of limitation provisions in other jurisdictions. ${ }^{67}$ Most pertinently, it can aid judicial understanding of the English statutory developments that Canada's second-wave reforms mirrored. When the House of Lords in Pirelli declined to infer a general principle of discoverability into the interpretation of the English Limitation Act 1939, it constrained considerations of discoverability to those provisions in which Parliament specifically provided for it. ${ }^{68}$ This conservative approach to statutory interpretation has seemingly dissuaded English judges from looking to the interpretive understandings of analogous provisions abroad. Yet, the statutory provision in the Limitation Act $1980 \mathrm{E} \& \mathrm{~W}$ - that limitation on an action based on fraud, concealment, or mistake "shall not begin to run until the plaintiff has discovered the fraud, concealment or mistake (as the case may be) or could with reasonable diligence have discovered $i t^{\prime \prime 9}$ — is clearly paralleled in Canadian limitation statutes and in the interpretative principle of discoverability. ${ }^{70}$ Indeed, it was English legislation and cases that provided "the source for the development of the Canadian rule." ${ }^{\text {1 }}$ Canada's understanding of discoverability can, in the relevant contexts, usefully inform the adjudicative approach in England and elsewhere. ${ }^{72}$

65. See e.g. Marine Liability Act, SC 2001, c 6, s 14(1); Bank Act, SC 1991, c 46, s 272(3); Competition Act, RSC 1985, c C-34, s 36(4)(a)(i). See Mew, Limitations, supra note 2 at Appendix B, C.

66. See Mew, Limitations, supra note 2 at paras 1.73-1.86.

67. Christine French, "Time and the Blamelessly Ignorant Plaintiff: A Review of the Reasonable Discoverability Doctrine and Section 4 of the Limitation Act 1950" (1998) 9 Otago L Rev 255 at 262-63.

68. See Pirelli, supra note 27 at 10, 14.

69. Limitation Act 1980 (E\&W), s 32(1) [Limitation Act $1980 \mathrm{E} \& W$ ] [emphasis added].

70. Rafuse, supra note 1 at 224. See Erik S Knutsen, "Limitation Periods and the Symbiosis of Capacity and Discoverability" (2003) 237 Ann Rev Civ Litig 237 at 241.

71. See Mew, Limitations, supra note 2 at para 3.29.

72. Andrews, supra note 18 at 593, citing Limitation Act 1980 E\&W, supra note 69 (noting that s 32(1) of the Limitation Act $1980 \mathrm{E} \& \mathrm{~W}$ is "important if 'discoverability' does not become the general 'starting-date' test" in England (ibid at 593, n 18)); Law Reform Commission of Ireland, Limitation of Actions, Report 104 (2011) (noting that modern limitation regimes "owe much to the pioneering work in the 1980s in Canada of the Alberta Institute of Law Research and Reform” (at 28)). 


\section{THE EXCEPTION: ERROR OF LAW}

The divergence in approaches to the law of limitation in Canada and Englandthe contrast between Nielsen and Pirelli-likely accounts for why jurists have not previously ventured to compare the relationship between the laws of limitation and mistake across these respective jurisdictions. That is unfortunate. While claims in restitution for mistake of law have proliferated in England owing to the perceived advantage that the discoverability provision in the English Limitation Act allows, ${ }^{73}$ equivalent pleadings in Canada have been constrained specifically by reference to the discoverability principle. The two jurisdictions adopted polar opposite positions when it came to the discoverability of mistakes of law. Important jurisprudential insights emerge from both sides of the Atlantic.

Owing to Canada's federal structure and its entrenched Constitution, the resolution of errors as to the law has been a more familiar feature of the judicial role in Canada than in England. In working through arguments testing the scope of discoverability, Canadian courts have honed a significant caveat to the principle. This was succinctly stated in Hill v Alberta: "Discoverability refers to facts, not law. Error or ignorance of the law, or uncertainty of the law, does not postpone any limitation period." 74

Whereas in England the courts had (until very recently) come to hold that a mistake as to a point of law is discoverable "when the point has been authoritatively resolved by a final court," 75 in Canada the running of limitation on actions arising from a mistake of law is explicitly not postponed by discoverability. At first blush this seems counterintuitive. In developing the discoverability principle, Canadian jurisprudence appeared to embrace a comparatively liberal understanding of limitation provisions. Yet the courts adhere to a conservative stance in cases of

73. Charles Mitchell, "End of the Road for the Overpaid Tax Litigation?" (2017-18) 9 UKSC YB 1 at 7.

74. Supra note 48 at 336 .

75. Test Claimants in the Franked Investment Income Group Litigation $v$ Commissioners of Her Majesty's Revenue and Customs, [2016] EWCA Civ 1180 at para 372 [FII Test Claimants v HMRC (CA)], applying Deutsche Morgan Grenfell Group Plc v Inland Revenue, [2006] UKHL 49 [Deutsche Morgan Grenfell]. See Steven Elliott, Birke Häcker \& Charles Mitchell, "Introduction" in Steven Elliott, Birke Häcker \& Charles Mitchell, eds, Restitution of Overpaid Tax (Hart, 2013) at 4 . The UK Supreme Court recently abandoned this precedent and overruled Deutsche Morgan Grenfell in Test Claimants in the Franked Investment Income Group Litigation v Commissioners for Her Majesty's Revenue and Customs [2020] UKSC 47 [FII Test Claimants v HMRC (SC)]. 
mistake of law. In such cases, error or mistake ${ }^{76}$ does not postpone a limitation period. This is despite the fact/law distinction in restitutionary actions having been eschewed by the SCC, ${ }^{77}$ and despite discoverability being a principle of general application. ${ }^{78}$ English courts, meanwhile, seem to have pursued a conservative interpretive position on discoverability generally-declining to imply the principle into the words of the Limitation Act-while liberally embracing the principle in the one type of action where Canadian jurisprudence explicitly excludes it. Indeed, it was only one year after the SCC had affirmed discoverability as a "general rule" of interpretation ${ }^{79}$ that this exception to the principle was recognized in a case arising from void legislation. ${ }^{80}$

Canada's error-of-law exception is frequently applied in the jurisprudence, but has been fleetingly acknowledged in the scholarship. ${ }^{81}$ The discussion that follows unpacks the Canadian rule. For succinctness, the discussion focuses on cases arising out of the province of Alberta, though the rule has been endorsed across Canada's common law provinces. ${ }^{82}$ Alberta's Limitation of Actions Act 1980

76. These terms are synonymous. Thus, the "mistake of law" rule in Bilbie is known in other jurisdictions as an "error of law" rule. See Bilbie v Lumley, (1802) 2 East 469 [Bilbie]. See Scottish Law Commission, Judicial Abolition of the Error of Law Rule and its Aftermath, (Discussion Paper 99) (Scottish Law Commission, February 1996); Helen Silving, "The Unknown and the Unknowable in Law" (1947) 35 Cal L Rev 352 at 362. See also Salna v Awad, 2011 ABCA 20 at para 28 [Salna v Awad Alta CA].

77. Air Canada, supra note 3 at 1201, La Forest J; Canadian Pacific Air Lines, supra note 3 at 1156, La Forest J.

78. Rafuse, supra note 1 at 224 .

79. Ibid.

80. Costello v Calgary (City) (1987), [1988] 1 WWR 379 (Alta QB) [Costello 1987 Alta QB].

81. CfLionel Smith, "The Timing of Injustice" in David Dyzenhaus \& Mayo Moran, eds, Calling Power to Account: Law, Reparations, and the Chinese Canadian Head Tax Case (University of Toronto Press, 2005) at 299.

82. Mew, Limitations, supra note 2 at para 3.52, n 78. See also Tucker v Fortune Financial Corp, (11 March 2003) Ontario 00-GD-48868, 00-GD-48870 (Ont Sup Ct) at 16 [Tucker]; Milbury $v$ Nova Scotia, 2007 NSCA 52 at para 27 [Milbury]; Laite v Younge, 2016 NWTSC 42 at para 20 [Laite]; Templanza $v$ Wolfman, 2016 ABCA 1 at para 19 [Templanza]; Lorencz $v$ Talukdar, 2017 SKQB 389 at paras 27-28, 34 [Lorencz]; Goyetche et al v International Union of Operating Engineers et al, 2019 NBCA 16 at para 40 [Goyetche]. Cf Rarie v Maxwell (1998), 168 DLR (4th) 579 [Rarie]; Beaudoin et al v Conley, 2000 MBCA 83 at para 63 [Beaudoin]. The Alberta Court of Appeal initially resisted the introduction of the Nielsen and Rafuse discoverability principle, but it ultimately came to be afforded broad application. A discoverability principle was codified in the Alberta Limitations Act. See Costigan v Ruzicka (1984), 13 DLR (4th) 368 (Alta CA); 98956 Investments Ltd (Receiver of) v Fidelity Trust Co (1987), 89 AR 151 at para 28 (CA) (CanLII); ALRI Limitations, supra note 38 at 26-27; Roach, supra note 20 at 40-41; Alberta Limitations Act, supra note 59, s 3(1)(a). 
treated "actions grounded on ... mistake" in a materially similar way to the English Limitation Act $1980 .{ }^{83}$ Yet, it was Albertan precedent that first determined that the principle of discoverability could not serve to postpone limitation in cases of "mistake" as to the law. This common law exception endures under Canada's reformed provincial limitations legislation. ${ }^{84}$ So it remains important that it is properly understood.

\section{A. DISCOVERABILITY AND MISTAKE: COSTELLO, MCWHORTER, AND HILL}

Canada's discoverability exception edged into common law understanding through three cases stemming from the Court of Queen's Bench of Alberta. Each case had a similar trajectory: an initial transaction, followed by litigation leading to a judgment exposing a flaw in the legal basis for the transaction, followed by an application to the court (in light of the judgment) to rectify the situation outside of the ordinary period of limitation. Appreciation of the factual circumstances elucidates the courts' rationale for developing the rule.

The first case to hold that discoverability does not extend time for errors of law was Costello $v$ Calgary (City). ${ }^{85}$ This was a damages claim filed against the City of Calgary after the plaintiffs successfully challenged a 1972 by-law that provided for expropriation of their property ${ }^{86}$ The City had taken possession of the plaintiffs' motel and land in 1974. In 1976, the plaintiffs sought a declaration that the by-law was void. Though their public law challenge initially failed at trial $^{87}$ and before the Court of Appeal of Alberta, ${ }^{88}$ it succeeded before the SCC, which declared the City's by-law void ab initio and ordered the return of the plaintiffs' property. ${ }^{89}$ Two years after the SCC's judgment, the plaintiffs

83. Limitation of Actions Act 1980, supra note 42. Although s 4(1)(e) of the Limitation of Actions Act 1980 expressly referred only to a subjective inquiry (into when the claimant discovered the cause of action), by operation of the interpretive principle of discoverability time would not begin to run on actions grounded on mistake until the plaintiff discovered, or could with reasonable diligence have discovered, the cause of action. See Limitation Act $1980 \mathrm{E} \& \mathrm{~W}$, supra note 69, s 32(1)(c) (mirroring s 4(1)(e) of the Limitation of Actions Act 1980).

84. HOOPP Realty, supra note 62 at paras 174-220; Ambrozic, supra note 62 at paras 29-32, 59; Waap, supra note 62 at paras 123-26; Stewart Estate, supra note 62 at para 197; Miller, supra note 62 at paras 91-100; Pecharsky, supra note 62 at paras 90-99. For summarized principles, see Condominium Plan No 0625385, supra note 62 at para 20. See also Mew, Limitations, supra note 2 at paras 3.48-3.53.

85. See supra note 80 .

86. See Bauman, supra note 38 at 74-75.

87. Costello v Calgary (City) (1980), 109 DLR (3d) 723 at 729 (Alta QB).

88. See Costello et al v City of Calgary (1981), 123 DLR (3d) 256 (Alta CA).

89. Costello and Dickhoff $v$ City of Calgary, [1983] 1 SCR 14. 
issued proceedings against the City in trespass and wrongful taking, claiming $\$ 10$ million in damages.

In these proceedings, Justice Virtue accepted that discoverability extended to claims in trespass. ${ }^{90}$ But he rejected the plaintiffs' contention that the SCC's judgment in 1983 gave rise to their damages action. The judgment was declaratory of the plaintiffs' rights; it did not create them. It was not, then, a materially significant event for discerning when the plaintiffs could have "discovered" their grievance against the City. ${ }^{91}$ The material facts that had supported the initial action for declaratory relief "would also have supported an action for damages." 2 Accordingly, despite having failed before the lower courts, the plaintiffs were considered capable of discovering their damages action at the outset. Justice Virtue stated, "A claimant does not have to find out from a court by a declaratory judgment his position as to liability in order to be in possession of the material facts upon which a claim for damages can be commenced." ${ }^{\prime 3}$ It was therefore the date of the expropriation-not the date of the SCC's determination of the plaintiffs' rights-from which time under the Limitation of Actions Act started to run. It was at that point that the plaintiffs had the material facts needed to assert their public law action. It was the same for their private law action. Accordingly, the plaintiffs' claim ought to have been filed by 1976 at the latest - that is, within two years of the unlawful expropriation ${ }^{94}$ —and it was, by 1985 , well out of time. ${ }^{95}$

Justice Virtue's reasons in Costello were subsequently endorsed in Mc Whorter $v$ Alberta, ${ }^{96}$ a case in which Justice Andrekson broadened the discoverability principle's reach. McWhorter arose from an error in the transfer of land to a municipal district under tax recovery proceedings in 1943. The Registrar of Land Titles had mistakenly included subsurface mines and minerals in the new certificate of title-the rights to which ought to have remained with the original owner, Meyers. The property was sold in 1946 to a private purchaser, Krautt, without noting the reservation on mines and minerals. The following

90. Costello 1987 Alta QB, supra note 80, citing Nielsen, supra note 1; Rafuse, supra note 1.

91. Rafuse, supra note 1 at 224.

92. Ibid.

93. Ibid.

94. Limitation of Actions Act 1980, supra note 42, s 51(f).

95. On further appeal, that latter finding was overturned, for reasons unconnected to discoverability, though Justice Virtue's reasons were not directly disturbed. See Costello 1989 Alta CA, supra note 10, leave to appeal to SCC refused, (1990) 65 DLR (4th) viii (25 January 1990).

96. McWhorter Alta QB, supra note 48 at para 24 (CanLII). See Hill v Alberta Alta CA, supra note 48 at 338 . 
year, the registrar purported to "correct" the error by amending Krautt's title and issuing Meyers a new certificate of title; but three-and-a-half decades later, on the application of Krautt's estate, the Court of Appeal of Alberta held that this "correction" had been ultra vires the registrar's powers and was of no effect.97 As a result, in 1981, the registrar cancelled the Meyers certificate of title and issued a new certificate in favour of Krautt's estate. The beneficiaries of Meyers' title then filed against the Alberta Land Titles Assurance Fund, contending that the registrar's mistakes had deprived them of their property interest. Was their claim statute-barred, or had it been brought "within six years from the date when the deprivation took place"?98 In a new round of litigation, Justice Andrekson extended discoverability to actions under the Land Titles Act. ${ }^{99}$ But he rejected the plaintiffs' contention that the Court of Appeal's judgment in 1980 had materially affected their legal position vis-à-vis the Registrar of Land Titles. Citing Costello, Justice Andrekson averred: ${ }^{100}$

The judgment of our Court of Appeal in Krautt v Paine supra was not, in my view, a "material fact on which the plaintiffs' case is based"; rather, it was a determination of law. In my view the plaintiffs would have had full notice of deprivation when they were in possession of all of the relevant facts upon which the Court of Appeal made its determination in Krautt supra.

On appeal, the Court of Appeal sidestepped the first issue ${ }^{101}$ but agreed that, regardless, it was the registrar's error in 1943-not the court's order in 1980 - that had deprived the plaintiffs of their rights. ${ }^{102}$ The evidence indicated that this error (and the plaintiffs' cause of action) could have been discovered

97. Krautt's estate had contended that Krautt had been a bona fide purchaser for value of the entire parcel of land, and issued proceedings seeking a declaration that the estate owned the mines and minerals. See Krautt v Paine, [1980] 6 WWR 717.

98. Land Titles Act, RSA 1942, c 205, s 167 (a).

99. McWhorter Alta QB, supra note 48 at paras 15-19 (CanLII). Cf Nicholas Rafferty, "McWhorter v Reg., North Alta. Land Registration Dist.," Case Comment, (1988) 57 Alta LR (2d) 335.

100. McWhorter Alta QB, supra note 48 at para 23 (CanLII).

101. McWhorter CA, supra note 48 ("we are not agreeing or disagreeing with the learned chambers judge when he found a discoverability rule inside the limitation period" at 5).

102. Ibid at 3-4. 
at the latest by $1973,{ }^{103}$ when the registrar-identifying the potential errorhad registered a caveat on the certificate of title. The plaintiffs' action, issued in 1984, was time-barred for that reason. Though the Court of Appeal of Alberta affirmed this outcome, it acknowledged the unfairness that limitation provisions can yield even applying discoverability. The solution, though, lay not in creative adjudication. While the plaintiff had no enforceable right, the court considered it "a proper case for the Government to consider an ex gratia payment." 104

The Court of Appeal of Alberta sought to settle the law in Hill v Alberta. ${ }^{105}$ Mr. Hill had, in 1977, procured a mortgage over his wife's property without her knowledge or consent. Mrs. Hill uncovered details of the mortgage in 1981 and complained to the Law Society but did not immediately challenge the mortgage. She made no payments on it. In 1982 the new mortgagee commenced foreclosure proceedings. Mrs. Hill successfully resisted foreclosure before the Court of Queen's Bench of Alberta, ${ }^{106}$ but she lost on appeal, ${ }^{107}$ and in 1987 a foreclosure order was issued, followed by an order of eviction. ${ }^{108}$ Having lost her case and her home, Mrs. Hill filed against the Land Titles Assurance Fund in 1988. ${ }^{109}$ The question again arose: When was it that "the deprivation took place" for the purpose of the governing six year limitation period? ${ }^{110} \mathrm{Mrs}$. Hill contended that the court's eviction order had deprived her of her interest in the property. The Court of Appeal of Alberta disagreed. Justice Côté held: "In 1987 the Court of Appeal only determined the law and did not create anything, and its judgment was not a fact .... The judgment was not a fact needed for a cause of action, nor a fact needing discovery (if discoverability applies)." ${ }^{111}$ The court's judgment had "only confirm[ed] what has existed all along" - that the mortgage over Mrs. Hill's

103. On the evidence it was not clear whether the registrar's purported "correction" of the certificates of title in 1946 should have alerted Meyers to the mistaken transfer. But following the transfer to Meyers's beneficiary, there was evidence that the beneficiary's solicitor had notice of a potential “'tax transfer' error," and in any event Justice Andrekson was satisfied that the deprivation was discoverable when the registrar filed a registrar's caveat on notice in 1973. See McWhorter Alta QB, supra note 48 at paras 30-34 (CanLII).

104. McWhorter CA, supra note 48 at 5.

105. Hill v Alberta CA, supra note 46, leave to appeal to SCC refused, [1994] 1 SCR viii (10 February 1994).

106. Paramount Life Insurance Company v Hill, [1985] 6 WWR 340 at para 87 (AltaB QB) (CanLII) (declaring the mortgage null and void).

107. Paramount Life Insurance Company v Hill (1986), 34 DLR (4th) 150 (Alta CA).

108. Hill v Alberta CA, supra note 48 at 332-35 (summarizing the factual history).

109. Hill $v$ South Alberta Land Registration District, [1991] 5 WWR 448 (CanLII) (Alta QB).

110. Ibid at para 7, referencing Land Titles Act, RSA 1980, c L-5, s 168(1)(a).

111. Hill v Alberta CA, supra note 48 at 338. 
property was valid. ${ }^{112}$ It was the registration of that mortgage that had deprived her of an interest in her property. As Mrs. Hill had discovered the mortgage more than six years before she claimed against the Assurance Fund, she was time-barred. The scope of the discoverability principle was thus stated to encompass "facts, not law," nor "[e] rror or ignorance of law, or uncertainty of the law." ${ }^{113}$ This principle has since been endorsed and affirmed across Canada's provinces. ${ }^{114}$

\section{B. THE DECLARATORY THEORY OF ADJUDICATION}

Woven throughout these cases is the idea that judicial determinations on points of law do not affect the interpretation of limitation statutes. In each case, the judges drew a distinction between discovering the "material facts" upon which the claim was based and discovering the law by which those facts grounded a right of action. Whereas the courts accepted that certain facts would be undiscoverable until some material event had occurred (e.g., Mrs. Hill uncovering the fraudulent mortgage), ${ }^{115}$ the law was not understood in this way. The disputed points of law were, rather, characterized as background to the events that gave rise to the claims. It was the factual events that were material. Whether or not the plaintiff understood the legal implications of the facts did not bear on the question of whether the cause of action had arisen. ${ }^{116}$ So, on this approach, it could not bear on the running of limitation. As it is the law that informs one's understanding of legal implications, judicial elaborations of the law, it seems, manifestly are not relevant to the limitation inquiry.

The legal philosophy that underpins this idea is the declaratory theory of adjudication. This philosophy, Chief Justice Bayda opined in Re Edward, "has become so elementary that most courts now readily apply it without making reference to it and perhaps without even recognizing that they are using it." 117 It is evoked in the references in Hill to the Court of Appeal of Alberta's judgments as having "declared" or "confirm[ed]" or "determined the law," rather than having

112. Ibid at 338-39.

113. Ibid at 336 .

114. Mew, Limitations, supra note 2 at para 3.52, n 78. See also Tucker, supra note 82 at 16; Milbury, supra note 82 at para 27; Laite, supra note 82 at para 20; Templanza, supra note 82 at para 19; Lorencz, supra note 82 at paras 27-28, 34; Goyetche, supra note 82 at para 40. CfRarie, supra note 82; Beaudoin, supra note 82 at para 63.

115. Hill v Alberta CA, supra note 48.

116. Ibid (stating "I can lose my ownership but once. It is not lost anew when the courts note the fact" at 338-39).

117. Edward v Edward Estate (1987), 39 DLR (4th) 654 at 661 (Sask CA) [Re Edward]. See Fleming $v$ Hanna (1994), 124 Nfld \& PEIR 30. 
"create[d] anything." 118 William Blackstone solemnized the declaratory theory as a basic feature of common law adjudication that differentiates the judicial role from the legislative. ${ }^{119}$ Whereas Parliament legislates prospectively, courts are constrained to interpret the law consistently across cases. Because the nature of adjudication is backward-looking-articulating what the law was in each case that comes before the court-a judge's rulings are generally understood to elucidate what already was. Judicial decisions can thus be seen to operate both prospectively and retrospectively. ${ }^{120}$ They are prospective in that a judgment serves as precedent for resolving future issues. They are retrospective because they clarify with hindsight the law that governed parties' interactions. Canada's error-of-law rule, being premised on the idea that judicial adjudication does not "change" the law, assumes that a judgment elucidating a plaintiff's error on a point of law does not give rise to any new condition that might require "discovering." It does not give rise to a change in the plaintiff's circumstances in the way that the finding of a fraudulent mortgage document does.

Despite fervent critiques of the "Blackstonian theory," 121 the principle prevails through Canada's error-of-law exception. The exception is of broad application. It has been applied in cases where a plaintiff has held a mistaken understanding of the law-namely, when the plaintiff was ignorant as to the governing legal authorities and principles, or misjudged their relevance. It has similarly been applied in cases where the law itself was in error-that is, where a principle of law has been overruled or a legislative provision declared void and of no legal effect. This is readily demonstrable in the case law.

\section{MISTAKEN UNDERSTANDING OF THE LAW}

McWhorter and Hill both concerned mistaken understandings of the law. They are examples of legal misjudgement. For a period of time, the plaintiffs believed that they owned title to property without the defendants' encumbrance. By this they

118. Hill v Alberta CA, supra note 48 at 336, 338-39.

119. Commentaries on the Laws of England, vol 1 (Clarendon Press, 1765) at 69-70. See Munster v Lamb (1883), LR 11 QBD 588 (CA), Brett MR.

120. Re Edward, supra note 117 at 661; Canada (AG) v Hislop, 2007 SCC 10 at para 83 [Canada $v$ Hislop]. See Samuel Beswick, "Retroactive Adjudication" (2020) 130 Yale LJ 276 [Beswick, "Retroactive Adjudication"].

121. See e.g. Lord Reid, "The Judge as Law Maker" (1972) 12 J Soc Pub Teachers L 22; Aruna Nair, "'Mistakes of Law' and Legal Reasoning: Interpreting Kleinwort Benson v Lincoln City Council' in Robert Chambers, Charles Mitchell \& James Penner, eds, Philosophical Foundations of the Law of Unjust Enrichment (Oxford University Press, 2009) 373 at 390-91. See Canada v Hislop, supra note 120 at para 93. 
laboured under a mistake of fact, since the properties were in fact encumbered by the defendants' proprietary claims. Even after the defendants' rival claims came to light, the plaintiffs continued to believe that the law gave their own claims precedence. That they were mistaken in their understanding of the law, and in its application to their circumstances, was ultimately confirmed by the Court of Appeal of Alberta's judgments. On the declaratory view, the court's judgments did not remove any right of the plaintiffs over the properties; they merely confirmed that the plaintiffs had no right to assert, and that the plaintiffs had been mistaken for thinking otherwise.

This precedent has not been confined to discoverability as a principle of common law, nor limited to cases concerning proprietary claims. It has been invoked in actions arising in the law of tort, breach of contract, statutory duty, and unjust enrichment. Less than a year after Hill was decided, the Court of Appeal of Alberta applied it to a dispute of a kind that, in England, ${ }^{122}$ became the quintessential impetus for the extension of limitation: A claim for restitution of mistakenly overpaid taxes.

\section{IGNORANCE OF THE LAW}

The case was Royal Canadian Legion Norwood (Alberta) Branch $178 v$ Edmonton. ${ }^{123}$ The issue was simple. Between 1971 and 1986, the plaintiff had been assessed for, and paid, municipal taxes on its property. It had done so unaware that the Municipal Taxation Act exempted land owned by, and primarily used for, branches of the Royal Canadian Legion. ${ }^{124}$ The city assessor had known of the exempting provision, but mistakenly thought that it did not apply to the plaintiff. It was not until May 1987 that the plaintiff first learned of its possible eligibility under the Act. The plaintiff sought restitution from the City of its overpaid taxes back to 1971.

The City pleaded limitation. ${ }^{125}$ The trial judge held that time was postponed until the plaintiff discovered the mistake and that its restitution claim, filed in

122. Elliott, Häcker \& Mitchell, supra note 75 at 4.

123. 111 DLR (4th) 141 (Alta CA) [Royal Canadian Legion Norwood Alta CA].

124. Municipal Taxation Act, RSA 1980, c M-31, s 25(1)(g). See Royal Canadian Legion Norwood (Alberta) Branch $178 v$ Edmonton, [1992] 6 WWR 265 at paras 5-6 (Alta QB) (CanLII) [Royal Canadian Legion Norwood Alta QB].

125. It was agreed that the Limitation of Actions Act 1980 governed the case. See Limitations of Action Act 1980, supra note 42, s 4(1)(e); Royal Canadian Legion Norwood Alta QB, supra note 124 at para 58; Royal Canadian Legion Norwood Alta CA, supra note 123 at 146. The limitation period on taxes in arrears did not apply to the claim. See Tax Recovery Act, RSA 1980, c T-1, s 30(1) [Tax Recovery Act]. 
March 1990, was timely. ${ }^{126}$ The Court of Appeal of Alberta disagreed. ${ }^{127}$ Notably, it did so on the basis that the statutory tax exemption was discoverable within the ordinary six-year period of limitation (thus negating the justification for extending time). In the alternative, the court reasoned that the plaintiff's mistaken understanding of the law was not relevant to the question of discoverability at all. The pertinent question for the court was "whether it is the 'discovery' of the facts or of the law that is at issue in the computation of the limitation period." 128 The court considered that it was when the plaintiff had discovered the facts that grounded its claim that the cause of action accrued. It was not when the plaintiff came to realize the legal significance of those facts. The Norwood Legion had known in May 1971 "all the facts relevant to the effect on it ... of the Municipal Taxation Act." 129 That the plaintiff had not known the law "did not postpone the limitation period of six years." 130

Plaintiffs who are ignorant of the law are expected to inform themselves by, if necessary, retaining a lawyer. ${ }^{131}$ So in Brandner $v$ Alberta, a plaintiff who filed a civil suit against a police officer could not pray in aid discoverability after erroneously assuming that he could not sue until after the criminal charges wrongfully brought against him had been dropped. ${ }^{132}$ Familiarity with the legal process, hiring of counsel, and collection of evidence are not constituent elements of a legal claim. The limitation clock does not stop for parties who take no or inadequate steps to apprise themselves of the law and proceed on an erroneous assumption of their legal rights and powers.

These principles hold despite the SCC's judgment in Rafuse, in which limitation was postponed some nine years after the commission of an error of law. Rafuse was a claim against solicitors for negligence in the execution of a mortgage transaction. The appellant mortgagee had received from its solicitors a certificate of title in 1969 recording the mortgage. In 1977, in the course of foreclosure proceedings, the validity of the mortgage was challenged as contravening the Nova Scotia Companies Act, which prohibited companies from assisting financially in their own share purchases. ${ }^{133}$ The trial court held that the

126. Royal Canadian Legion Norwood Alta QB, supra note 124 at para 27.

127. Royal Canadian Legion Norwood Alta CA, supra note 123 at 150.

128. Ibid at 149 [emphasis in original].

129. Ibid.

130. Ibid.

131. VAH v Lynch, 1998 ABQB 622 at para 47.

132. 2014 ABQB 211 at paras 43-44. Cf HF Pension Trustees Ltd v Ellison, [1999] PNLR 894 at 904-905 (Ch); Sandhu v HM Revenue and Customs, [2017] EWHC 60 (QB) at para 27.

133. Companies Act, RSNS 1967, c 42, s 96(5). 
mortgage did not violate the Act and was valid; ${ }^{134}$ the Nova Scotia Court of Appeal held it was void in part ${ }^{135}$ and the SCC held that it did violate the Act and was void in its entirety. ${ }^{136}$ Following that decision in 1980, the mortgagee sued its solicitors, who pleaded limitation. ${ }^{137}$ Their alleged negligence ${ }^{138}$ had occurred in 1968, when they arranged the mortgage in ignorance of the Companies Act's restriction. ${ }^{139}$ This, they argued, was a mistake of law for which discoverability could not apply to postpone the running of limitation. ${ }^{140}$

The SCC properly held that the proceedings had been brought within time. The limitation period did not, though, run from the Court's judgment in 1980, which had finally resolved the parties' ignorance of the law. ${ }^{141}$ Of importance was that the mortgagee had reasonably relied on its solicitors' advice and representations. ${ }^{142}$ While the solicitors had no excuse for overlooking their own mistake, the pertinent question was when could the mortgagee reasonably have discovered their solicitors' negligence? The Court held that it was when the mortgage was challenged in 1977 that the mortgagee could reasonably have learned that the security was potentially invalid and unenforceable, and thus that their solicitors had acted negligently. Proceedings having been filed within six years of that date, ${ }^{143}$ their claim in professional negligence succeeded. ${ }^{144}$ The mortgagee in Rafuse could be considered to be in a similar position to the plaintiffs in McWhorter and Hill. ${ }^{145}$ It was not the plaintiffs' mistake of law that justified the postponement of limitation. It was their reasonable reliance on the defendants (the solicitors in Rafuse and the Registrar of Land Titles in McWhorter and Hill). Accordingly, time ran from the courts' assessment of when the plaintiffs could reasonably have discovered and challenged those defendants' mistakes.

134. Central and Eastern Trust Co v Stonehouse Motel and Restaurant Ltd (1977), 81 DLR (3d) 495 (NS SC).

135. Irving Oil Ltd. $v$ Central and Eastern Trust Co (1978), 89 DLR (3d) 374 (NS CA).

136. Central and Eastern Trust Co v Irving Oil Ltd, [1980] 2 SCR 29.

137. Statute of Limitations 1967, supra note 42, s 2(1)(e) (providing that actions in contract and tort must be commenced "within six years after the cause of ... action arose").

138. The courts also disagreed over whether the solicitors had been negligent. See Rafuse, supra note 1 at $210-14$.

139. Ibid at 219-20.

140. The respondents succeeded on this argument before the Court of Appeal (but the Supreme Court overturned it on further appeal). See Central Trust Co v Rafuse et al (1983), 147 DLR (3d) 260 (NS CA).

141. Rafuse, supra note 1 at 219-24.

142. Ibid at 216.

143. Statute of Limitations 1967, supra note 42, s 2(1)(e).

144. Rafuse, supra note 1 at 224.

145. See Part II(A), above. 


\section{MISJUDGEMENT OF THE LAW}

As the three tiers of contradictory judgments in Rafuse demonstrate, it is not uncommon for those learned in the law to err in its interpretation or application. One might misconstrue a legal provision, as did the tax assessor in Royal Canadian Legion Norwood. Or, the state of the law may be uncertain such that competent lawyers would disagree on it, as in Rafuse. As with ignorance, adjudicative resolution of a misjudgement of the law does not trigger discoverability so as to postpone the running of limitation. Time will not stay paused where a plaintiff unreasonably fails to appreciate the legal significance of their circumstances. Nor will limitation be postponed for plaintiffs who learn by a judgment that they have instigated the wrong legal process in pursuit of an otherwise legitimate claim.

Justice Slatter in Papaschase Band No. $136 v$ Canada (AG) summarized this first implication as follows: ${ }^{146}$

What must be discoverable is the facts underlying the claim; ignorance of the law or subsequent discovery that a cause of action exists at law does not extend the limitation .... Subsequent clarification or evolution of the law does not postpone the discovery of the material facts so as to extend the limitation period.

Discoverability does not postpone limitation until the point at which a plaintiff has recognized the significance of the material facts. Thus, in Luscar Ltd. $v$ Pembina Resources Ltd., the Court of Appeal of Alberta overturned a trial judge's ruling that "a cause of action ... does not arise and the limitation period does not commence to run until the injured party is," or "should be deemed to be," "aware of his rights." 147 To the question of what must be discovered, the court found its answer in Royal Canadian Legion Norwood: It is the facts, not the law. ${ }^{148}$ Addressing the undiscovered breach of contract at issue, the court concluded that the claimants' failure to "determine that they had a cause of action" was "not a burden which the appellant must bear." 149

The second implication was demonstrated in Salna $v$ Awad. ${ }^{150}$ The claimant (Dover) sought to recover investment payments that it had made (from March 2003) on behalf of a defaulting joint venture partner (Awad). After failing,

146. 2004 ABQB 655 at para 136, considering Limitation of Actions Act, RSA 1980, c L-15, s 4(1) (e). See also Stobbe v Paramount Investments Inc, 2013 ABCA 384 at paras 13, 15.

147. [1995] 2 WWR 153 at 71 [Luscar CA], rev'g (1991), 85 Alta LR (2d) 46 at 83 (QB) [Luscar QB] [emphasis in original]. See New Brunswick v LeBlanc, 2013 NBCA 9 at paras 13-15.

148. Luscar CA, supra note 147 at 74-75, citing Royal Canadian Legion Norwood CA, supra note 123 at 149 .

149. Luscar CA, supra note 147 at 79-80.

150. Salna v Awad Alta CA, supra note 76. 
in protracted litigation in Ontario, ${ }^{151}$ to set-off the amounts owed against Awad's share of revenue, Dover commenced unjust enrichment proceedings in Alberta in January 2007. Awad responded by pleading, inter alia, limitation. The Court of Queen's Bench of Alberta considered that Dover's unjust enrichment claim had become warranted only after the Ontario court had determined in August 2006 that Dover was not entitled to set-off Awad's debt by withholding revenues. ${ }^{152}$ On that basis, Dover's action would fall within the two-year limitation period. ${ }^{153}$ But the Court of Appeal of Alberta disagreed. ${ }^{154}$ It found that Dover's error was apparent from a 2004 judgment of the Ontario court. ${ }^{155}$ More pertinently, Dover was wrong to presume that its error of law would postpone the running of limitation at all: 156

Dover's mistaken belief that it was entitled to withhold payment of the [joint venture] revenues was not a basis for postponing the running of time. The mistake in this case was one of law rather than fact. Generally speaking, discoverability in Alberta law refers to facts, not law. ... [E]rror or ignorance of law, or uncertainty of the law, does not postpone any limitation period.

The Court of Appeal of Alberta characterized the Ontario judgment as having clarified the law and the parties' respective rights under it. The Ontario judgment did not create new rights and it was not materially relevant to Dover's restitutionary claim. The limitation period ran, instead, from when Awad had

151. In a judgment delivered on 21 September 2004, Justice Spence held that Dover was not entitled to set-off the production revenues against Awad's unpaid share of expenses and directed Dover to pay over the withheld funds. Awad v Dover Investments Ltd (2004), 133 ACWS (3d) 788 (Ont Sup Ct). However, before entering judgment, Justice Spence heard further evidence which caused him, on 3 February 2005, to set aside that direction. Awad $v$ Dover Investments Ltd (2005), 1 BLR (4th) 173. Justice Spence then received further submissions and varied his order again on 30 August 2006, concluding that there was no proper basis for Dover to withhold funds from Awad. His formal judgment, released on 11 January 2007, directed payment of the net withheld funds to Awad, without prejudice to Dover's rights to sue Awad. Salna v Awad Alta CA, supra note 76 at paras 18-19.

152. Salna v Awad, 2010 ABQB 419 at paras 24-25 [Salna v Awad Alta QBD].

153. Alberta Limitations Act, supra note 59, s 3(1)(a)(iii) (limiting claims to a remedial order to " 2 years after the date on which the claimant first knew, or in the circumstances ought to have known, ... that the injury ... warrants bringing a proceeding").

154. Salna v Awad Alta CA, supra note 76 at para 26.

155. Ibid at para 27.

156. Ibid at para 28 . 
become enriched to the detriment of Dover. ${ }^{157}$ Plaintiffs are expected to follow correct legal process. A judgment pointing out that they have not done so does not give rise to, or extend, a cause of action. ${ }^{158}$

\section{MISTAKEN LAW}

It is a "mistake" to act pursuant to a positive law that is itself found to be invalid. Costello $v$ Calgary illustrates acting under a mistaken law: For over a decade, an ultra vires by-law remained in effect until the SCC declared it void. ${ }^{159}$ The Court's judgment revealed not only that the by-law was unlawful, but that actions taken under its authority - the expropriation of the plaintiffs' property-were also unlawful. They were the result of a mistake of law.

Likewise, when a judicial decision is overruled or a new legal precedent is established, it may be that those who acted under an earlier understanding of the law will in hindsight be found to have laboured under a mistake. Judicial decisions of remedial invalidity are presumed to operate retroactively. ${ }^{160}$ But they do not, in Canada, implicate discoverability to postpone the running of limitation.

\section{OVERRULED OR NEW PRECEDENT}

An argument that discoverability should apply to situations where the law "changes" was raised in Cunningham v Pinckney. ${ }^{161}$ The plaintiffs had sought to introduce into proceedings under the Fatal Accidents $A_{c t}^{162}$ a new cause of action that had become recognized as part of provincial law following the Court of Appeal of Alberta's judgment in Duncan Estate $v$ Baddeley. ${ }^{163}$ Baddeley had set a new precedent in upholding the viability of a fatal accidents claim by a deceased child's estate for lost future earnings. In Cunningham, the Cunningham family contended that it was not until Baddeley that they could pursue such an

157. Ibid at paras 30-36. The pertinent question was when had "all of the various elements of the cause of action" occurred? The Court of Appeal found that Awad was not enriched when Dover made the payment on his behalf. It was when Awad accepted the benefit of a farm-out agreement on 6 August 2005. This was the point that Awad "turned the item to account." And proceedings were commenced within two years of that date.

158. See also Laasch v Turenne, 2012 ABCA 32 [Laasch Alta CA]; Hope v RM of Parkdale \#498, supra note 47 at para 62.

159. Costello 1987 Alta QB, supra note 80 at paras 2-3.

160. Canada v Hislop, supra note 120 at para 83.

161. 2001 ABCA 38 at para 2 [Cunningham].

162. RSA 1980, c F-5.

163. (1997), 145 DLR (4th) 708 (Alta CA) [Baddeley]. 
action in their own proceedings. ${ }^{164}$ The chambers judge at first instance accepted the argument. ${ }^{165}$ The Court of Appeal of Alberta rejected it. ${ }^{166}$ The unanimous judgment noted that in the ordinary course a novel precedent is not understood to "change" the law and, even where it was, the authorities ran against extending discoverability to situations where the law changes: ${ }^{167}$

The law is often uncertain, and deciding whether the law of a given province had changed on some particular date, or had merely become clearer or less clear, would be a difficult exercise. The Luscar, Hill, and Royal Canadian Legion cases expressly say that uncertainty of the law does not postpone limitation periods. The rationale for the bar to relying upon ignorance of the law extends far beyond ignorance of clear law.

The following year, the SCC rejected a similar argument in Wewaykum Indian Band $v$ Canada. ${ }^{168}$ There, two First Nations bands had filed proceedings against each other and against the federal Crown claiming that but for breaches of fiduciary duties by the Crown, each band would possess the other's land. The event that precipitated this litigation was the SCC's decision in Guerin $v$, which recognized for the first time the right of a band to claim financial compensation from the Crown "for breach of fiduciary duty in the disposition of part of its reserve."169 The Court in Wewaykum Band unanimously rejected the argument that the governing limitation period ${ }^{170}$ was postponed until the claimants had become aware of the novel cause of action upheld in Guerin. Justice Binnie for the Court found that the bands had received independent legal advice by the 1930s and had been aware of the material facts on which their later claims were based. ${ }^{171}$ The neighbouring bands had elected not to disturb each other by pursuing legal action at the time. What had changed upon release of Guerin was that the bands became aware of the possibility of compensation from the Crown. But, Justice Binnie held, "[a]wareness of the availability of a claim in equity for financial compensation against the Crown does not ... turn what the band regarded as an equitable situation into an inequitable situation." 172 The band's "discovery" that

164. Cunningham v Irvine-Adams, 1999 ABQB 517 at para 14.

165. Ibid at para 56-58.

166. Cunningham, supra note 161.

167. Ibid at para 5.

168. 2002 SCC 79 [Wewaykum Band].

169. Ibid at para 64, citing Guerin v The Queen, [1984] 2 SCR 335 [Guerin].

170. Limitation Act, RSBC 1979, c 236, s 14(1); Federal Court Act, RSC 1985, c F-7, s 39(1). The Limitation Act was incorporated by reference to the Federal Court Act.

171. Wewaykum Band, supra note 168 at para 123.

172. Ibid at para 124 . 
it could have brought an action against the Crown did not turn their prior views of their positions into newly actionable claims. ${ }^{173}$

\section{VOID LEGISLATION}

Costello showed that a judicial determination that a by-law is ultra vires is not in itself a materially relevant event for the purposes of determining when a cause of action is discoverable. ${ }^{174}$ Herman $v$ Alberta (Public Trustee) ${ }^{175}$ and Goodswimmer $v$ Canada (Attorney General) ${ }^{176}$ show that the same result follows when the impugned provision is in a statute. The Herman claims were for damages under the Fatal Accidents Act ${ }^{177}$ arising from a deadly airplane crash in 1997. When proceedings were filed in 1999, the legislation did not expressly allow adult children to claim bereavement damages, and so no such claim was filed. In 2004, the Court of Appeal of Alberta in Ferraiuolo Estate $v$ Olson ${ }^{178}$ struck down the age and marital restrictions in the Fatal Accidents Act ${ }^{179}$ for violating the Charter equality rights of married and older children. ${ }^{180}$ In light of Ferraiuolo, the adult children plaintiffs in Herman sought bereavement damages. ${ }^{181}$

The Court of Queen's Bench of Alberta considered the amendments to be timely particularizations of the plaintiffs' initial claims, ${ }^{182}$ but proceeded in obiter to dismiss Ferraiuolo's relevance. Justice RP Marceau averred that Ferraiuolo had not added anything to what the Herman plaintiffs could themselves have pleaded when they first filed suit. ${ }^{183}$ It had been open to them to challenge the constitutionality of the age and marital restrictions, just as it had been for the Ferraiuolo plaintiffs. Their claim for bereavement "was discoverable as soon as

173. See also Stewart Estate, supra note 62 at para 206.

174. See Part II(A), above.

175. 2005 ABQB 337 [Herman].

176. 2017 ABCA 365, leave to appeal to SCC dismissed, 37899 (5 July 2018)

[Goodswimmer Alta CA].

177. Supra, note 162.

178. 2004 ABCA 281 [Ferraiuolo].

179. Supra note 160 , s $8(2)$ (c).

180. Canadian Charter of Rights and Freedoms, s 15(1), Part I of the Constitution Act, 1982, being Schedule B to the Canada Act 1982 (UK), 1982, c 11.

181. Herman, supra note 173.

182. Ibid at paras 33-35, applying Limitations Act, RSA 2000, c L-12, s 3(1)(a).

183. Herman, supra note 175 at para 36-37. 
all of the underlying facts required to make out that claim were known, i.e., in October, 1997." 184

A similar point was made in Goodswimmer. ${ }^{185}$ Ten years after holding a referendum in which the Sturgeon Lake Band approved a settlement of historic grievances with Canada and Alberta, the SCC in Corbiere $v$ Canada ${ }^{186}$ declared the legislative provisions on which the Band's referendum had been modelled as unconstitutional. ${ }^{187}$ The Goodswimmer plaintiffs argued that Corbiere rendered their settlement agreement void, which they could only have discovered once Corbiere was handed down, rendering their lawsuits against the Crown timely. ${ }^{188}$ These arguments failed both at first instance and on appeal. First, the courts found that the holding of a referendum had been a prudent, but not a legal, precondition for approving the settlement, so Corbiere was not binding authority. ${ }^{189}$ Second, even if it were binding, it was "untenable" that Corbiere could have had the effect of postponing limitation in the Goodswimmer proceedings. ${ }^{190}$ The courts affirmed the error-of-law exception. ${ }^{191}$ The Corbiere decision had not given rise to any material facts that had not already been available to the Goodswimmer plaintiffs. What it had done was expose a potential legal argument that they had failed to consider. The plaintiffs' subsequent discovery of their potential error of law did not postpone their time for litigating that argument. Moreover, "strong policy reasons mitigate[d] against" co-opting a judicial decision as a basis for reopening disputes in non-related parties' cases. ${ }^{192}$ Discoverability being deemed irrelevant, the Band's lawsuit was time-barred.

184. Ibid at paras 38, 40; Limitations Act, RSA 2000, c L-12, ss 6(1), (2). Ultimately, discoverability was not a material issue because, even aside from the claimants' success on their first argument, the applications were found to fall within an exception in the Act.

185. Goodswimmer Alta CA, supra note 176. See also Stoney Nakoda Nations v Canada, 2016 ABQB 193, affd 2017 ABCA 432.

186. (Minister of Indian and Northern Affairs), [1999] 2 SCR 203 [Corbiere].

187. Indian Act, RSC1985, c I-5, s 77(1).

188. Goodswimmer $v$ Canada (AG), 2016 ABQB 384 at paras 419, 459 [Goodswimmer Alta QB].

189. Ibid at paras 415, 423; Goodswimmer Alta CA, supra note 185 at para 91.

190. Goodswimmer Alta QB, supra note 188 at para 460; Corbiere v Canada, [1994] 1 FC 394, affd in part [1997] 1 FC 689. It is curious that everyone involved assumed that the Supreme Court's decision in Corbiere was the pertinent event, when it was the Federal Court in 1993 that first issued a declaration that s 77(1) was unconstitutional. Arguably, even if the Band's arguments were right, they should have issued proceedings after the Federal Court's decision was handed down, in which case they still would have been time-barred.

191. Goodswimmer Alta QB, supra note 188 at para 460, affd 2017 ABCA 365 at para 119.

192. Goodswimmer Alta QB, supra note 188 at para 423-24, affd 2017 ABCA 365 at para 92. See Part IV, below. 
To the extent that these cases hold that adjudicative declarations of ultra vires legislation are irrelevant considerations, the holdings are apt. As Part III, below, will show, these cases sit at odds with English jurisprudence, where disapplication of discriminatory legislation is thought to provide a basis for extending the temporal reach of a cause of action.

\section{THE ERROR OF THE EXCEPTION}

Despite its prevalence in case law, Canada's exception to the discoverability principle is jurisprudentially shallow. The "facts, not law" mantra is often rehearsed without explanation of how law is to be distinguished from fact or how the exception is reconcilable with discoverability being a "general rule" for interpreting the running of limitation on causes of action. ${ }^{193}$ Nor has the conflict with English precedent been acknowledged. In practice, the error-of-law rule may overly curtail rights by protecting those who make legal rules (the Crown and public authorities) and impeding those who have been harmed by unjust laws.

\section{A. RESURRECTING THE FACT/LAW DISTINCTION}

The error-of-law exception is conceptually flawed. It rests on a distinction that the SCC has already renounced. During the previous two centuries, it was conventional to invoke the maxim ignorantia juris non excusat to bar recovery of payments made under a mistake of law. The rationale, given in Bilbie $v$ Lumley, was that, "[e]very man must be taken to be cognisant of the law; otherwise there is no saying to what extent the excuse of ignorance might not be carried. It would be urged in almost every case." 194 This mistake-of-law bar on civil recovery has since been abandoned across the common law world. ${ }^{195}$ The rule rested on a misconception that because mistake-of-law cannot be invoked as a defence by accused wrongdoers, that plaintiffs should also be barred from grounding claims in mistake of law. But plaintiffs in such cases are not seeking to be excused from the law. Rather, they are invoking the mistake positively to justify their claim for recovery. ${ }^{196}$

193. Rafuse, supra note 1 at 224.

194. (1802) 2 East 469 at 449, Lord Ellenborough CJ.

195. Mitchell McInnes, The Canadian Law of Unjust Enrichment and Restitution (LexisNexis, 2014) at 380.

196. Peter Birks, An Introduction to the Law of Restitution, revised ed (Clarendon Press, 1989) at 164-67; E Allan Farnsworth, Alleviating Mistakes: Reversal and Forgiveness for Flawed Perceptions (Oxford University Press, 2004) at 143-48. 
The SCC redressed this problem in Air Canada v British Columbia ${ }^{197}$ and Canadian Pacific Air Lines v British Columbia. ${ }^{198}$ These conjoined cases concerned two distinct mistakes of law. The former was a case of mistaken law: The Court held that taxes levied prior to British Columbia's Gasoline Tax Act ${ }^{199}$ being declared constitutionally invalid were recoverable in restitution. ${ }^{200}$ The latter was a case of mistaken application of the law: The legislation itself was valid, ${ }^{201}$ but it had been misapplied to the claimants. ${ }^{202}$ Both reasons prima facie substantiated the airlines' claims for restitution against the Crown. Justice La Forest, delivering the lead judgments, held that "the distinction between mistake of fact and mistake of law should play no part" in determining the claimants' restitution claims. ${ }^{203}$ Justice Wilson concurred "that moneys paid under a mistake of law should, like moneys paid under a mistake of fact, be recoverable." 204

If mistake-of-law can provide a reason for restitution, then it must be a material element of a cause of action, and against such actions time can only run when all of the elements-including mistake — can be discovered. The error-of-law exception - which holds that a mistake of fact may postpone time, but a mistake of law may not-reintroduces the fact/law distinction into the question of when a mistake becomes salient. Yet, like the rule in Bilbie v Lumley, this rule offers no practicable framework for distinguishing law from fact. Is ignorance of a relevant statutory provision, for instance, an error of law (as Royal Canadian Legion Norwood held) ${ }^{205}$ or a failure to appreciate "a matter of fact"? 206 The distinction becomes so "blurred" as to be unhelpful. ${ }^{207}$ Reliance on it will only reanimate, in the limitation inquiry, arbitrariness previously jettisoned from the cause-of-action inquiry.

197. Air Canada, supra note 3.

198. Canadian Pacific Air Lines, supra note 3.

199. 1948, RSBC 1960, c 162.

200. Air Canada, supra note 3 at 1186.

201. Social Services Tax Act, RSBC 1979, с 388.

202. McInnes, supra note 195 at 382.

203. Air Canada, supra note 3 at 1201. Justice Wilson dissented in the substantive Air Canada decision but explicitly expressed support for abolishing "the traditional rule as to the irrecoverability of monies paid under a mistake of law" (ibid at 1214).

204. Canadian Pacific Air Lines, supra note 3 at 1158.

205. Royal Canadian Legion Norwood Alta CA, supra note 123.

206. James Edelman \& Elise Bant, Unjust Enrichment, 2nd ed (Hart, 2016) at 186 (discussing David Securities Pty Ltd $v$ Commonwealth Bank of Australia, (1992), 175 CLR 353).

207. Pitt $v$ Holt, [2013] UKSC 26 at para 104. 


\section{B. INSULAR DEVELOPMENT}

The Canadian jurisprudence can be criticized for its insular development. The error-of-law exception has emerged without regard to English precedent, despite the countries' limitation statutes' shared origins. Peculiarly, until very recently England's courts had taken the opposite view to Canada's. English precedent had held that limitation did not begin to run on mistake-of-law claims until an "authoritative" judgment finally resolves the impugned point of law. ${ }^{208}$ The English rule was illogical and indefensible, as elsewhere explained. ${ }^{209}$ Its presence nevertheless refuted the Canadian presumption of discoverability's sheer irrelevance. Both jurisdictions could learn from each other to reach a coherent middle ground on the problem.

\section{A NOT-SO-“GENERAL RULE”}

The SCC in Rafuse styled discoverability as a "general rule" for interpreting how limitation runs against causes of action. ${ }^{210}$ It has since reaffirmed this interpretive position. ${ }^{211}$ This position might at first seem to vindicate a prominent critique that has been advanced concerning the scope of the English discoverability rule for mistakes. ${ }^{212}$ It was held in Phillips-Higgins $v$ Harper that England's discoverability provision postpones time only "where the mistake is an essential ingredient of the cause of action." ${ }^{213}$ In an early edition of their seminal text, Robert Goff and Gareth Jones criticized this constrained scope and suggested that the English discoverability rule for mistake should be "read generously" so as to reach the "desirable result" of postponing limitation in all cases of material mistake. ${ }^{214}$ Prior to being elevated to the High Court of Australia, James Edelman too advocated for a broader interpretive approach. Edelman argued that there was nothing in the text, history, or principle of the English Limitation Act 1980 that "warrants a requirement that mistake be an element of the cause of action" in order for

208. FII Test Claimants v HMRC (CA), supra note 75 at para 372. The UK Supreme Court recently overruled this line of precedent, although it did not adopt a Canada-style approach and continues to apply discoverability to mistakes of law: FII Test Claimants v HMRC (SC), supra note 75 at para 243.

209. See Beswick, "Discoverability of Mistakes of Law," supra note 4.

210. Rafuse, supra note 1 at 224.

211. Pioneer Corp, supra note 5 at paras 34-38; cf ibid at paras 140-50, Côté J, dissenting.

212. Limitation Act $1980 \mathrm{E} \& \mathrm{~W}$, supra note 69, s 32(1) (quoted in Part I(D), above).

213. [1954] 1 QB 411 at 419 (CA) [emphasis added], affd in Test Claimants in the Franked Investment Income Group Litigation v Inland Revenue, [2012] UKSC 19 at paras 49-50, 61-62, Lord Walker. Ibid, at paras 181-83, Lord Sumption.

214. The Law of Restitution, 4th ed (Sweet \& Maxwell, 1993) at 769. 
a plaintiff to benefit from the discoverability provision's extended limitation period. ${ }^{215}$ He contended that it should be sufficient that a claimant laboured under a relevant mistake-more precisely, that the discoverability rule should postpone limitation whenever a mistake was "causally significant to the relief sought," such that the reason for the plaintiff bringing an action for relief was a consequence of their mistake. ${ }^{216}$ Accordingly, in a case where tax was paid as a consequence of the plaintiff's mistaken belief that the law required it, Edelman argued that the postponed period of limitation should not commence until the plaintiff could have discovered their mistake of law. ${ }^{217}$ The period should not vary depending on the cause of action-it should not matter, for instance, whether the action for relief was framed as unjust enrichment for a mistake or under the constitutional right to restitution of unlawfully exacted taxes. ${ }^{218}$ Discoverability should apply whether or not the mistake was essential to pleading the action.

It is clear that Canadian jurisprudence does embrace an expansive role for discoverability. Part I, above, showed that the postponed limitation period is not constrained to specific contexts as it is in England. Yet, Part II's analysis, above, controverts Edelman's thesis. It affirms a rule that rejects postponement where the reason for the plaintiff's delay in suing was an error of law. In Royal Canadian Legion Norwood, for example, the plaintiffs paid taxes for fifteen years under a mistaken belief that the law required it, while the tax assessor accepted the payments under a mistaken belief that a statutory exception did not apply. ${ }^{219}$ In Costello $v$ Calgary and Herman $v$ Alberta, the claimants faced legislative provisions that purported to impede their claims, and promptly filed damages actions after those provisions were struck down as ultra vires. ${ }^{220}$ The claimants in Cunningham $v$ Pinckney and Wewaykum Indian Band $v$ Canada acted similarly once new precedent exposed to them their legal errors, ${ }^{221}$ as did the claimants in McWhorter $v$ Alberta and Hill v Alberta, who issued proceedings once their titles to property were stripped by court order. ${ }^{222}$ And in Luscar v Pembina Resources

215. "Limitation Periods and the Theory of Unjust Enrichment" (2005) 68 Mod L Rev 848 at 851 .

216. Ibid at 853. Correspondingly, "where the 'gist of the action' was the misconduct of the defendant rather than the claimant's mistake, the limitation period would not be extended" (ibid).

217. Ibid, citing Deutsche Morgan Grenfell, supra note 75.

218. Woolwich Equitable Building Society v Inland Revenue, [1993] 1 AC 70; Kingstreet Investments Ltd $v$ New Brunswick (Department of Finance), 2007 SCC 1 [Kingstreet Investments].

219. See Part II(C)(1), above.

220. See Part II(D)(2), above.

221. See Part II(D)(1), above.

222. See Part II(A), above. 
and Salna $v$ Awad, the claimants were delayed in bringing their respective actions owing to mistakes as to their legal rights. ${ }^{223}$ Yet the discoverability arguments failed in each case. The claimants' errors of law were held to be irrelevant to the determination of limitation on their actions. The errors did not inform the question of discoverability.

Even the landmark judgment of Kingstreet Investments $v$ New Brunswick did not invoke discoverability, though the taxing regulation that the SCC found to be unconstitutional had operated since 1983 without legal challenge until 2001.224 Instead, the Court held that the restitution claims were subject to the ordinary limitation period. The six-year period commenced at the time of the erroneous payments of tax. ${ }^{225}$ Discoverability was not even addressed in the litigation. ${ }^{226}$ Carving out mistake-of-law actions undermines the claim that discoverability is a "general rule" for interpreting the running of limitation on causes of action in Canada.

\section{OVER-CURTAILING RIGHTS OF ACTION}

Excluding errors of law from the discoverability inquiry can lead to actions expiring before a claim can feasibly be brought. This has been a particular concern for claims advanced by Indigenous groups concerning historic grievances against the Crown. The error-of-law exception is a significant obstacle to such claims. ${ }^{227}$ If plaintiffs are able to prove that they had been unable to bring suit during the ordinary period of limitation, why should the law rigidly prohibit such proceedings?

223. See Part II(C)(2), above.

224. Kingstreet Investments, supra note 218.

225. Ibid at para 61.

226. Instead, the appellants had argued (unsuccessfully) that their restitution claims were not subject to the Limitation of Actions Act, RSNB 1973, c L8, at all. See Kingstreet Investments Ltd v New Brunswick, 2005 NBCA 56 at para 40; Michael Pal, "The Supreme Court of Canada's Approach to the Recovery of Ultra Vires Taxes: At the Border of Private and Public Law" (2008) 66 UT Fac L Rev 65 at 88-94 (arguing "that limitation periods should not apply to the recovery of ultra vires taxes." (ibid at 93)).

227. Goodswimmer Alta QB, supra note 188 at para 460 (affd 2017 ABCA 365);

Wewaykum Band, supra note 168. Cf Department of Justice Canada, Attorney General of Canada's Directive on Civil Litigation Involving Indigenous Peoples (Department of Justice Canada, 2019). 
The error-of-law exception is also descriptively unpersuasive. There are two important judgments it cannot explain. ${ }^{228}$ The first is the SCC's decision in Rafuse. ${ }^{229}$ Recall that the Court held that the plaintiff mortgagee was within time in 1980 to sue its solicitors for negligent mortgage execution in 1968, even though the governing limitation period was only six years. The judgment predates Costello's articulation of the error-of-law exception and did not specifically address it. The Court held that it was only when the mortgage was challenged in foreclosure proceedings in 1977 that the mortgagee could reasonably have learned that the certificate of title provided by its solicitors was potentially invalid and unenforceable, and thus that the solicitors had acted negligently. The Court applied the discoverability principle, though the plaintiffs error (i.e., believing it had a valid mortgage) was ultimately one of law. This seems right. Had the Court treated the error as an exception to discoverability, the plaintiff's action would have been time-barred before it could reasonably have been discovered, since in law the company suffered the damage in 1968 when it failed to acquire an interest in the property as security for its loan. ${ }^{230}$ As the plaintiffs could not have been expected to second-guess their solicitors at the time, applying an error-of-law exception would have led to an injustice.

The second judgment is the Court of Appeal of Alberta's decision in McWhorter $v$ Alberta. The court held that the plaintiffs had been deprived of their rights in 1943 when the Registrar of Land Titles mistakenly stripped the owner of her interest in the property's mines and minerals. ${ }^{231}$ From that date, the plaintiffs erred in assuming good title in the subsurface property. The court nevertheless averred that the limitation period might not have run until 1973, when a caveat was registered on the certificate of title. ${ }^{232} \mathrm{Had}$ the plaintiffs not

228. Cf Peel (Regional Municipality) v Canada (1986), [1987] 3 FC 103 at para 27 (WL) (which was wrongly decided and overturned in [1992] 3 SCR 762 at 804-805). Cf David A Crerar, "The Restitutionary Class Action: Canadian Class Proceedings Legislation as a Vehicle for the Restitution of Unlawfully Demanded Payments, Ultra Vires Taxes, and Other Unjust Enrichments" (1998) 56 UT Fac L Rev 47 at 85-86; Robert Chambers, "Restitution of Money Paid to Third Persons: Peel (Regional Municipality) v The Queen" (1993) 57 Sask L Rev 325 at 339-40.

229. See WH Hurlburt, "Hill v Registrar: Limitation of Actions, the Assurance Fund and the Discoverability Rule" (1993) 31 Alta L Rev 692 at 705 (explaining the decision in Rafuse, on the basis that "it may be that non-discoverability of law will lead to "non-discoverability" of fact so as to prevent a limitation period from running"); Rafuse, supra note 1.

230. Ibid at 219-20.

231. McWhorter Alta CA, supra note 48 at para 3.

232. Ibid at paras 3-4. The Court declined to reach a conclusion on this point. 
been dilatory in filing their action at that time, then, their claim might not have been time-barred.

These cases indicate that the error-of-law exception is misconceived. The idea that juridical events are not a basis for postponing the running of limitation periods is sound. But this is not because errors of law are never discoverable. Rather, it is because they are presumptively always discoverable.

\section{APPLICATION OF PRINCIPLE, NOT EXCEPTION TO PRINCIPLE}

The Canadian rule should be reconceived as a presumption that errors of law are discoverable, the burden of which is on plaintiffs to rebut. Discoverability should apply to all errors - whether of fact or law. The purpose of discoverability is to ensure that time does not expire before a reasonably diligent plaintiff could have brought an action. Courts should not be constrained from considering the circumstances faced by the particular plaintiffs before them in determining whether their claims are time-barred. ${ }^{233}$

\section{A. THE LAW'S DISCOVERABILITY}

There have been few concerted efforts to justify Canada's error-of-law exception. In a case note on Hill, William Hurlburt acknowledged that an injustice may follow "no less because it is ignorance of law rather than ignorance of fact," but contended that the balance of policy considerations favours the error-of-law exception to discoverability, stating: ${ }^{234}$

For one thing, it would be enormously difficult for defendants to show that plaintiffs knew or ought to have known about the relevant law. For another, judicial decisions continually change the law and often confer new remedies or make old ones more widely available ... . Allowing plaintiffs to sue for old claims under the new rules would create much injustice to defendants. Extending the "discoverability" rule to include "discoverability" of law would defeat the policy objectives of limitations statutes. Not extending it is an exercise of appropriate judicial restraint.

These arguments are not robust. The first objection could be addressed by insisting that plaintiffs bear the burden of demonstrating (un)discoverability. The

233. See Alisia Adams, "Unforgiven Trespasses: Provincial Statutes of Limitations and Historical Interference with Indian Lands" (2001) 7 Appeal 32; Mayo Moran, "The Problem of the Past: How Historic Wrongs Became Legal Problems” (2019) UTLJ 421.

234. Hurlburt, supra note 229 at 703. 
second objection rests on an assumption of indeterminacy of limitation periods that is not an inevitable consequence of subjecting errors of law to discoverability. The categorization of errors of law as an exception to discoverability is problematic because it suggests that a fact/law distinction governs the interpretation of when actions arise even though the distinction does not govern the content of said actions. It leads to the inference that limitation periods on actions arising from errors of law would differ but for the courts' adherence to the exception. This inference is unsound. What is sound is the judicial inclination from which the exception stems: That judicial decisions should not bear upon when limitation runs against a claimant's mistake.

To appreciate why, we must reflect on the purpose of the discoverability principle: It is to provide that the time the legislature prescribes for suing a defendant does not expire before a plaintiff is able to bring an action. ${ }^{235}$ Discoverability is not concerned with when it would be practical or convenient for the plaintiff to sue. ${ }^{236}$ The driving question is when is it possible to do so. The prima facie answer is: When the elements of the cause of action are able to be discovered. A cause of action is "a factual situation the existence of which entitles one person to obtain from the court a remedy against another person." 237 An action in the tort of negligence, for instance, arises once a plaintiff $(\mathrm{P})$ is able to discover that a defendant (D) injured them, in circumstances where $\mathrm{D}$ should not have done so, and that the injury caused P loss. An action for restitution of mistakenly paid money arises once $\mathrm{P}$ is able to discover that they have paid $\mathrm{D}$ money by mistake in circumstances where, had $\mathrm{P}$ not been mistaken at the time, $\mathrm{P}$ would not have done so. Or, on the Garland approach, it arises once $\mathrm{P}$ is able to discover that there was no juristic reason for D's retention of the money. ${ }^{238}$ It is the material facts that inform the elements of a cause of action. It is the law that tells us when those elements will be actionable before the courts. Yet, when a mistake of law causes $\mathrm{P}$ to misidentify the propriety of D's conduct, or is itself an element of the cause of action, the mistake is necessarily relevant. That is obviously so where the cause of action is unjust enrichment and the unjust factor

235. KLB v British Columbia, 2003 SCC 51 at para 55.

236. Novak, supra note 20 at para 65.

237. Letang $v$ Cooper, [1965] 1 QB 232 at 242-43, endorsed in Markevich $v$ Canada, 2003 SCC 9 at para 27; Canadian Imperial Bank of Commerce v Green, 2015 SCC 60 at para 188; July $v$ Neal (1986), 32 DLR (4th) 463 (Ont CA) at 471; 1100997 Ontario Ltd v North Elgin Centre Inc, 2016 ONCA 848 at para 19. See also Zacks, supra note 10 at 169; French, supra note 67 at 255 .

238. Garland v Consumers' Gas Co, 2004 SCC 25 at para 40. See Kerr v Baranow, 2011 SCC 10 at para 32. 
is mistake of law. ${ }^{239}$ In such a case it makes no sense to assert that the mistake of law is irrelevant to the accrual of the cause of action. The action can only accrue once the mistake element has been, or could be, discovered.

The question, then, is not when can the action be discovered setting aside error or ignorance of the law. The question is when can its elements-including the mistake of law-be discovered such that the plaintiff would be in a position to plead the action? Stating the question in this way presupposes that we are operating under a "Blackstonian paradigm" of adjudication. ${ }^{240}$ The suggestion that there has been a mistake of law assumes that a plaintiff who in the past acted inconsistently with the law, as declared today, was mistaken in doing so. ${ }^{241}$ If a judicial decision as to the state of the law today had the jurisprudential effect of replacing previous valid law_-so that the new precedent operated only prospectively_-then a plaintiff could not be considered mistaken in the past when acting in accordance with the previous state of the law. No cause of action in mistake of law could arise. ${ }^{242}$ The declaratory theory holds that common law adjudication elucidates the law governing both future and past cases (i.e., both prospectively and retrospectively). Because the nature of adjudication is backward-looking, actions that were taken on the basis of some contrary view of the law must necessarily be considered to have been taken in error. ${ }^{243}$ It may only be with hindsight that a plaintiff discovers the "correct" state of the law, and thus the mistake. But on the theory that judicial decisions are declaratory of the

239. McInnes, supra note 195 at 380-83 (noting that the same result follows whether mistake is understood as an "unjust factor" or as negating a "juristic reason” under Garland v Consumers' Gas Co, supra note 238). See John D McCamus, "Unjust Enrichment, Existing Categories and Kerr v Baranow: A Reply to Professor McInnes” (2012) 52 Can Bus LJ 390 at 392-93; Steve Hedley, "What Is Happening to the Law of Unjust Enrichment?" in Paul Daley, ed, Apex Courts and the Common Law (University of Toronto Press, 2019) at 373-75.

240. Canada v Hislop, supra note 120 at para 86. Or, more contemporarily, "Dworkinian." See Duncan Sheehan, "What Is a Mistake?" (2000) 20 LS 538 at 560.

241. John Finnis, “The Fairy Tale’s Moral” (1999) 115 Law Q Rev 170; Allan Beever, "The Declaratory Theory of Law" (2013) 33 Oxford J Leg Stud 421 at 433-39.

242. See Part IV(D), below.

243. West Midland Baptist (Trust) Association Inc v Birmingham Corp (1969), [1970] AC 874 at 898-99, Lord Reid; National Westminster Bank plc v Spectrum Plus Ltd, [2005] UKHL 41 at para 12 [Re Spectrum Plus Ltd]. See also (in the criminal law context) Rv Cottrell, [2007] EWCA Crim 2016 at para 52, Sir Igor Judge P (“[f] or the time being the court is bound by what we shall identify as the declaratory principle of the common law"). Cf ibid at para 60; $R v$ Johnson, [2016] EWCA Crim 1613 at para 2 ("the Supreme Court identifies the law both prospectively and retrospectively"); David Ormerod, "Jogee: Not the End of a Legal Saga but the Start of One?" [2016] Crim L Rev 539 at 552; Karl Laird, "Joint enterprise: R v Johnson" [2017] Crim L Rev 216 at 218. 
law governing past events, the correct state of the law must be deemed to have been within reach at the time of the plaintiffs action. ${ }^{244}$ If it was not, there could be no "law" for the plaintiff to be mistaken of. Assuming, then, that there was a "correct" state of the law at the time of the (trans)action, we must consider how a plaintiff could have come to recognize it. Elsewhere I have proposed two tests that can assist this inquiry. ${ }^{245}$ Here, we need only appreciate two basic propositions in order to understand the correct characterization of Canada's error-of-law rule.

First, if discovery of "the law" is to be approached analogously to discovery of facts, then one point is clear: The accrual of an action does not depend upon the findings of a court. A plaintiff does not need "perfect knowledge" or certainty of the material facts that give rise to their action before the limitation period begins to run. ${ }^{246}$ Take, for example, the negligent personal injury tort. In some cases, an injury and its cause will be so obvious that a cause of action will be discoverable (and the limitation period will commence) even before the plaintiff seeks a medical opinion. In other cases, such as where the effects of an injury are latent, the action will be held to accrue once the injury is diagnosed. ${ }^{247}$ The situation is similar in respect of mistakes of fact. Where a plaintiff miscalculates their liability to tax, the error is discoverable once the plaintiff is in a position to realize their mistake. In no case is limitation deferred only until a court has made findings of fact that the plaintiff has suffered an injury of which the defendant was the cause, or that the plaintiff's payment was indeed in error. Discoverability concerns the plaintiff's ability to plead a case. It does not defer limitation until the issues in dispute are finally resolved. If it did, limitation acts would be hollow statutes. Thus, Mew affirms that: ${ }^{248}$

The discovery of a claim does not depend upon the plaintiff knowing that his or her claim is likely to succeed; the limitation period runs from when the prospective plaintiff has or ought to have had knowledge of a potential claim, and the later discover[y] of facts which change a borderline claim into a viable one does not postpone the discovery of the claim.

244. Sheehan, supra note 240 at 559-60; Andrew Burrows, "Common Law Retrospectivity" in Andrew Burrows, David Johnston \& Reinhard Zimmermann, eds, Judge and Jurist: Essays in Memory of Lord Rodger of Earlsferry (Oxford University Press, 2013) at 548. Cf Deutsche Morgan Grenfell, supra note 75 at paras 31, Lord Hoffmann, and 71, Lord Hope.

245. Samuel Beswick, "Discoverability Principles and the Law’s Mistakes" (2020) 136 Law Q Rev 139 at 150-54.

246. Mew, Limitations, supra note 2 at para 3.50.

247. Ibid at para 3.51 .

248. Ibid at para 3.56 [emphasis added]; see also Richard James, "The Law Commission Report on the Limitation of Actions" (2003) 22 CJQ 41 at 44; cf Edelman, supra note 215 at 853. 
This principle ties into a second proposition: That the limitation period on mistakes of law depends - in the ordinary way-upon whether the plaintiff could have discovered the mistake "by the exercise of reasonable diligence." 249 The burden of proof is on the plaintiff. 250 Where a plaintiff asserts that their error of law caused them to delay bringing proceedings, it is incumbent on them to demonstrate why this was so. If the plaintiff misunderstood their legal position, they must show why they could not have discovered their position sooner. If it was a statutory provision or legal precedent that stood in their way, the plaintiff must show why they could not have challenged the point of law earlier. In practice, this is often an insurmountable hurdle.

Laasch $v$ Turenne was a case of a misunderstood legal position. ${ }^{251}$ The plaintiffs thought that they could enforce in Alberta a judgment obtained in Montana via the expedited process in the Reciprocal Enforcement of Judgments Act. ${ }^{252}$ By the time they realized that they did not qualify under that $A c t,{ }^{253}$ the plaintiffs were out of time to enforce the judgment by an ordinary common law action. The discoverability principle did not assist them. The Court of Appeal of Alberta, citing Justice McLachlin in Novak $v$ Bond, ${ }^{254}$ held that the critical question was whether "a reasonable person would consider that someone in the plaintiffs position, acting reasonably in light of his or her own circumstances and interests, could — not necessarily should — bring an action." 255 That the plaintiffs themselves did not think to register the judgment in the ordinary way did not detract from the conclusion that, exercising reasonable diligence, the plaintiffs could have done so. Their error of law was discoverable at the outset of the litigation and so, even if the court had accepted the error as relevant, it could not serve as a basis for deferring the running of time.

A similar outcome has followed in cases where claimants faced court precedent ${ }^{256}$ or legislative provisions ${ }^{257}$ that purported to impede their claims. The courts dismissed the claimants' arguments on the basis that error of law

249. Rafuse, supra note 1 at 224 [emphasis added].

250. Mew, Limitations, supra note 2 at para 3.54 .

251. See Part II(C)(2), above.

252. RSA 2000, c R-6.

253. Laasch v Turenne, 2009 ABQB 267.

254. Novak, supra note 20 at para 81.

255. Laasch Alta CA, supra note 158 at para 19 [emphasis added]; cf Allison \& Co v Horner,

[2014] EWCA Civ 117 at paras 16, 19.

256. See Part II(D)(1), above.

257. See Part II(D)(2), above. 
was apparently irrelevant to the discoverability inquiry. ${ }^{258} \mathrm{~A}$ more principled approach would have recognized that errors of law may be relevant to parties' claims, but that such errors were nonetheless discoverable at the time of the impugned (trans)actions. The implication is that it was always possible for the plaintiffs, exercising reasonable diligence, to have challenged the law that they later pointed to as erroneous. That they did not think to do so does not mean that a plaintiff acting reasonably could not have done so. It is not essential to a claim that a court in separate proceedings first resolves the state of the law under which the plaintiffs found their complaint.

This recharacterization of the error-of-law rule reconciles the courts' discoverability jurisprudence with the idea that mistake of law is not a bar to recovery. ${ }^{259}$ In the first instance decision in Royal Canadian Legion Norwood, Justice Gallant averred that an error-of-law exception would conflict with the SCC's holding in Air Canada "that the distinction between mistake of fact and mistake of law is purely artificial and should not be given effect." 260 The point was not addressed on appeal, ${ }^{261}$ but this article's revised understanding avoids the conflict. Discoverability should govern mistakes of both fact and law. A plaintiff's failure to appreciate their position under the law is not invariably irrelevant to the running of limitation. But nor is it a matter that requires resolution by a court before a plaintiff can be in a position to discover their cause of action. Discoverability does not postpone the running of limitation until the point at which the legal issue in dispute has reached its adjudicative end. As with a mistake of fact, a mistake of law should prima facie be considered discoverable when it is made. ${ }^{262}$ It is for the plaintiff to overcome the burden of rebutting that presumption in order to benefit from the principle of discoverability.

\section{B. INSIGHT INTO ENGLISH CASES}

The revised approach would implement a shift from a bar on mistake-of-law arguments to a presumption that such mistakes are discoverable. English courts need not embrace Canada's general principle of discoverability in order to appreciate how this understanding might better inform their approach to mistakes

258. See also Dan Priel, "The Justice in Unjust Enrichment” (2014) 51 Osgoode Hall LJ 813 at 839 (contending that notions of property explain why in unjust enrichment "liability arise[s] at the moment of enrichment and not at the moment of learning of it").

259. Air Canada, supra note 3 at 1201; Canadian Pacific Air Lines, supra note 3 at 1156.

260. Royal Canadian Legion Norwood Alta QB, supra note 124 at para 43, citing Air Canada, supra note 3.

261. Royal Canadian Legion Norwood Alta CA, supra note 123 at 149.

262. Mew, Limitations, supra note 2 at para 3.94. 
of law. The common law of Canada preceded that of England in abandoning the distinction in the treatment of restitution actions founded on mistakes of fact and law. ${ }^{263}$ Canadian common law can also offer guidance toward re-evaluating English jurisprudence on the discoverability of mistakes of law.

The main difference between this article's revised approach and recent English doctrine concerns where the burden of proof lies. The revised Canadian approach rests on a presumption that the law can always (objectively) be discovered with reasonable diligence, even though it might be some time before a plaintiff (subjectively) discovers their mistake. ${ }^{264}$ Plaintiffs bear the burden of rebutting this presumption by demonstrating that their suit could not have been brought within the ordinary limitation period. ${ }^{265}$ The English approach did the opposite. It rested on a presumption that a disputed point of law is not reasonably discoverable until it has been "authoritatively" determined by a final court. ${ }^{266}$ This placed the effective burden of proof onto defendants to show that a plaintiff could have discovered their error of law sooner. It is a difficult burden to discharge. In practice, this presumption tended to extend indeterminately the running of limitation to the benefit of plaintiffs. In some cases, it enabled plaintiffs to defer the running of time until an appellate court ruled in their own case upon an impugned point of law, on the theory that such ruling renders the law discoverable. ${ }^{267}$ In other words, time would remain paused even after the plaintiff had brought an action.

Such a holding would be intolerable in Canada. In KLB v British Columbia, the SCC rejected an argument that plaintiffs were not statute-barred because they were unable fully to appreciate their personal injury actions, which arose from abuse suffered as children, even while their claims were being litigated. ${ }^{268}$ Chief Justice McLachlin held for the Court: ${ }^{269}$

This approach to reasonable discoverability is problematic. It rests on evidence that the plaintiffs lacked sufficient awareness of the facts even after they had brought their actions. Since the purpose of the rule of reasonable discoverability is to ensure that plaintiffs have sufficient awareness of the facts to be able to bring an action, the

263. Air Canada, supra note 3, discussed in Kleinwort Benson Ltd v Lincoln City Council, [1999] 2 AC 349.

264. Mew, Limitations, supra note 2 at para 3.94. See Sheehan, supra note 240 at 559.

265. Mew, Limitations, supra note 2 at para 3.54.

266. FII Test Claimants v HMRC (CA), supra note 75 at para 372, overruled by FII Test Claimants $v$ HMRC (SC), supra note 75 at para 243.

267. FII Test Claimants v HMRC, (CA), supra note 75 at para 373.

268. Supra note 230.

269. Ibid at para 55, cited in HOOPP Realty, supra note 62 at para 206. 
relevant type of awareness cannot be one that it is possible to lack even after one has brought an action.

Thus, even within a jurisdiction that embraced an expansive understanding of the discoverability of mistakes, the outcome that Goff, Jones, and Edelman advanced does not follow. ${ }^{270}$ These scholars considered that extending discoverability to mistakes of law generally would defer time for litigating whenever a judgment unexpectedly changes the law. ${ }^{271}$ Such a proposition is not supported by the Canadian authorities, either on their current or revised understanding. It would render limitation statutes ineffectual if limitation periods commenced only once arguments over the law (and its application to facts) were finally resolved in litigation. Such an approach does not reflect a sound understanding of discoverability either in Canada or in England.

\section{RELEVANCE TO THIRD-WAVE STATUTES}

Much of the doctrine discussed in this article arose from interpretations of Canada's second-wave limitation statutes. But this article's revised approach survives Canada's third-wave reforms, ${ }^{272}$ which centre limitation on the discoverability of "claims" rather than the accrual of "causes of action.," ${ }^{273}$ The key distinction is that the former depends upon whether damage or injury "warrants bringing a proceeding," whereas the latter does not. ${ }^{274}$ This consideration permits limitation to be postponed when a claimants' circumstances are such that "the costs and strains of litigation would be overwhelming," 275 the injury did not

270. $C f$ Part III(C), above.

271. Edelman, supra note 215 at 853; James Edelman, "Chief Justice French, Judicial Power and Chapter III of the Commonwealth Constitution" in Henry Jackson, ed, Essays in Honour of Chief Justice French (Federation Press, 2019) at 103-104. See also Francis Rose, "Lapse of Time: Limitation" in Peter Birks \& Francis Rose, eds, Lessons of the Swaps Litigation (Mansfield Press, 2000) at 379; Andrew Burrows, "Unjust Enrichment and Restitution" in The Oxford Handbook of The New Private Law, Andrew S Gold, et al, eds, (Oxford University Press, 2020) at 304.

272. HOOPP Realty, supra note 60 at paras 174-220; Ambrozic, supra note 60 at paras 29-32, 59; Waap, supra note 60 at paras 123-26; Stewart Estate, supra note 60 at para 197; Miller, supra note 60 at paras 91-100; Pecharsky, supra note 60 at paras 90-99. For summarized principles, see Condominium Plan No 0625385, supra note 60 at para 20. See also Mew, Limitations, supra note 2 at paras 3.48-3.53.

273. See Part $\mathrm{I}(\mathrm{C})$, above.

274. Zacks, supra note 10 at 166, 185. See e.g. Alberta Limitations Act, supra note 59, s 3(1)(a).

275. JNv Kozens, 2004 ABCA 394 at para 15 [Kozens]; Gayton v Lacasse, 2010 ABCA 123 at para 30 [Lacosse]; Champagne v Sidorsky, 2017 ABQB 557 at para 34 [Sidorsky]. See Amackv Wishewan, 2015 ABCA 147 at para 44 [Wishewan]. 
appear to be serious, ${ }^{276}$ the fruits of litigation were thought to be minimal or speculative, or "other personal circumstances combined to make it unfeasible to initiate an action." 277

These third-wave statutory schemes do not postpone time where claimants fail to take reasonable steps to inform themselves about the law, or to challenge points of law in the course of legal proceedings. The Court of Appeal of Alberta in Salna $v$ Awad was right to overturn the trial judge's holding that the plaintiff's unjust enrichment action in Alberta had not been "warranted" 278 until the Ontario Superior Court of Justice had dismissed its set-off claim in that province. ${ }^{279}$ Applying the error-of-law rule, the Court of Appeal of Alberta considered that the plaintiff's mistake of law "was not a basis for postponing the running of time" on its claim. ${ }^{280}$ The court could have reached the same outcome by inferring that the plaintiff's mistake of law was discoverable when it was made. ${ }^{281}$ Before he was elevated to the SCC, Justice Russell Brown held in Nipshank $v$ Trimble that Alberta's modern discoverability provision does not "allow for delaying the running of a limitation period until a plaintiff has secured legal advice that the injury 'warrants bringing a proceeding." 282 The inquiry is concerned with "the circumstances of the plaintiff herself or himself," not with the legal position of the plaintiff's case. ${ }^{283}$ Limitation commences once a plaintiff has the means of knowing that the defendant has inflicted an injury which warrants bringing a proceeding, whether or not the plaintiff has actual knowledge. ${ }^{284}$ His Honour properly concluded that "the plaintiff's legal position—which she will typically

276. See ALRI Limitations, supra note 38 at 33, 64, cited in Atlanta Industrial Sales Ltd v Emerald Management \& Realty Ltd, 2006 ABQB 255 at para 192; Keyland Development Corporation v Rocky View (Municipal District No 44), 2016 ABQB 735 at paras 109-10.

277. Kozens, supra note 275 at para 15; Lacasse, supra note 275 at para 30; Sidorsky, supra note 275 at para 34. See Nipshank v Trimble, 2014 ABQB 120 at para 12 [Trimble]; Sztuczka v Knebel, 2012 ABQB 72 at para 19; Schitthelm v Kelemen, 2017 ABQB 546 at para 213.

278. See e.g. Alberta Limitations Act, supra note 59, s 3(1)(a).

279. Salna $v$ Awad Alta CA, supra note 76 at paras 27-28, rev'g Salna v Awad QBD, supra note 152 at paras $24-25$.

280. Salna v Awad Alta CA, supra note 76 at para 28.

281. Limitations Act, SO 2002, c 24, Sch B, s 5(2). A presumption to this effect is found in section 5(2) of Ontario's Limitations Act which provides: "A person with a claim shall be presumed to have known of the matters referred to in clause (1)(a) [discoverability of claim] on the day the act or omission on which the claim is based took place, unless the contrary is proved." I thank Stephen Pitel for referring me to this source.

282. Trimble, supra note 271 at para 7.

283. Ibid at para 9, citing Novak, supra note 20 at para 81.

284. Trimble, supra note 277 at para 6 (quoting the familiar phrase of Côté JA in Hill v Alberta Alta CA, supra note 48 at 336). 
know from having received legal advice-is a given, and is therefore not a consideration to be applied." 285

\section{BEYOND THE BLACKSTONIAN PARADIGM?}

Courts across the common law world have on occasion averred that when judges overrule prior precedent, or deliver clearly "new" law, their decisions ought not to be shackled by the declaratory theory's demand for retroactivity. ${ }^{286}$ This is not the place to critique the judiciousness of prospective overruling. ${ }^{287}$ It is sufficient to recognize that where the technique of prospective overruling is employed, there will be no past "error" against which the limitation statute can run. If novel court decisions operated only prospectively, and not retroactively, it would not be a "mistake" to act in accordance with the law as understood before the court's judgment. ${ }^{288}$ Thus, in Goodswimmer $v$ Canada, the Court of Appeal of Alberta held that even if the impugned legislative provision at issue did bear upon the plaintiffs' case, policy considerations would militate against extending limitation on past settled transactions by reference to a later judicial declaration of unconstitutionality. ${ }^{289}$ It is only where a court accepts that there has been a material past error of law that this article's analysis of limitation on such errors is pertinent.

\section{CONCLUSION}

Over the past three decades, Canadian common law has embraced a rule that errors of law are irrelevant to the discoverability inquiry in the law of limitation.

285. Trimble, supra note 277 at para 13. See also the discussion in Quadrangle Holdings Ltd $v$ Coady, 2012 ABQB 22 paras 32-43.

286. Golak Nath v State of Punjab, 1967 AIR 1643 at 60, Subbarao CJ; Chevron Oil Co v Huson, 404 US 97 at 106-107 (1971); Murphy v Attorney General, [1982] IR 241 at 293-94,

O'Higgins CJ; Re Spectrum Plus Ltd, supra note 243 at para 34, Lord Nicholls; LCA 8925/04 Solel Boneh Building \& Infrastructure Ltd $v$ Estate of Alhamid [2006] (1) Isr LR 201 at paras 16-17, Barak P; Chamberlains v Lai, [2006] NZSC 70 at para 136, Tipping J; Hislop, supra note 120 at para 93; Masiya v State (CCT54/06) [2007] ZACC 9 at para 51; Khan v Bangladesh, ADC Vol IX (A), 10 (2012); Public Prosecutor v Hue An Li, [2014] SGHC 171 at para 124, Sundaresh Menon CJ. CfHa v New South Wales (1997), 189 CLR 465 at 503-504; HKSAR v Wa, [2006] 9 HKCFAR 614 at para 18, Li CJ.

287. See Beswick, "Retroactive Adjudication," supra note 120.

288. Charles Sampford, Retrospectivity and the Rule of Law (Oxford University Press, 2006) at 212-13.

289. Goodswimmer Alta CA, supra note 176 at para 92. See also Goodswimmer Alta QB, supra note 188 at paras 421-25. 
This rule is jurisprudentially shallow. It evokes the maligned fact/law distinction and creates problems in doctrine and policy. It gives rise to the possibility that the limitation clock will commence regardless of whether a plaintiff is reasonably able to discover their error of law and pursue a claim in light of it. Certainly, this rule is preferable to the recently-abandoned English approach, whereby the limitation clock could remain paused up until an impugned point of law was authoritatively determined by a final court. Canadian jurisprudence is right to eschew that path. But the error-of-law exception is an overcorrection.

This article has argued that both approaches are misconceived. The Canadian idea that juridical events are not a basis for postponing the running of limitation periods is sound. But that idea should not be understood as an exception to discoverability. It reflects, instead, the prima facie application of the discoverability principle. This is the middle path: that errors of law are presumptively discoverable when they are made.

\section{POSTSCRIPT}

Shortly before this article went to print, the Supreme Court of the United Kingdom handed down judgment in Test Claimants in the Franked Investment Income Group Litigation v Commissioners for Her Majesty's Revenue and Customs. ${ }^{290}$ A panel of seven Law Lords overruled the House of Lords' landmark judgment in Deutsche Morgan Grenfell Group Plc v Inland Revenue, ${ }^{291}$ which interpreted England's discoverability rule to postpone the commencement of limitation on claims in mistake of law "until the true state of the law is established by a judicial decision from which there lies no right of appeal." ${ }^{\prime 292}$ The Supreme Court unanimously held that this interpretation contravened the text and purpose of the limitation statute, was inconsistent with comparable precedents, and produced paradoxical and illogical consequences that frustrated Parliament's intention for the statute. ${ }^{293}$ The Supreme Court did not, however, pivot to a Canada-style interpretation. After careful consideration, a majority concluded that England's discoverability provision remains applicable to actions for relief from the consequences of a mistake of law. Instead, they adopted an approach

290. FII Test Claimants v HMRC (SC), supra note 75.

291. Deutsche Morgan Grenfell, supra note 75.

292. FII Test Claimants $v$ HMRC (SC), supra note 75 at para 8.

293. Ibid at paras 174, 213. 
consistent with that advanced in Part IV of this article. The President and Deputy President of the Supreme Court, delivering the joint lead opinion, concluded: ${ }^{294}$

That approach to the construction of the provision best gives effect to Parliament's intention to relieve claimants from the necessity of complying with a time limit at a time when they cannot reasonably be expected to do so, and does not have unacceptable consequences for the legal certainty which the 1980 [Limitation] Act is primarily designed to protect.

The Supreme Court's judgment is now-as the Law Lords themselves implicitly recognised-one of "the most important decisions on the law of limitation of recent times." ${ }^{295}$ The Law Lords comprehensively grappled with an issue that has received fleeting attention from Canadian courts to date. The judgment provides further impetus for judges to reconsider the discoverability of mistakes of law in Canada.

294. Ibid at para 243 (Lord Reed and Lord Hodge, joined by Lord Lloyd-Jones and Lord Hamblen); cf ibid at para 258 (Lord Briggs and Lord Sales, joined by Lord Carnwath, dissenting).

295. Ibid at para 1. 